\title{
30. GRAVITATIONAL COMPACTION PATTERNS DETERMINED FROM SEDIMENT CORES RECOVERED DURING THE DEEP SEA DRILLING PROJECT LEG 67 GUATEMALAN TRANSECT: CONTINENTAL SLOPE, MIDDLE AMERICA TRENCH, AND COCOS PLATE 1
}

\author{
Richard W. Faas, Department of Geology, Lafayette College, Easton, Pennsylvania
}

\begin{abstract}
A transect down the Guatemalan continental slope, across the Middle America Trench, and onto the Cocos Plate reveals significantly different conditions of sediment compaction. Factors responsible for these compaction states are (1) lithologic variation, (2) variable rates of lithostatic loading, (3) lateral and vertical tectonics, and (4) generation of gases through biochemical processes and/or gas hydrate decomposition.

In most cases, undercompaction appeared related to gas generation and rapid sedimentation rates, regardless of lithology. Overcompaction appeared related to lithification (including diagenetic effects) and sedimentation rates. Continental slope sediments showed predictable intervals of undercompaction, extending from 60 to about 200 meters below mudline, followed by overcompacted sediments to the base of the hole. Overcompaction throughout the entire sediment column at Holes 494 and 494A (Trench inner slope) may reflect lateral compressive stresses exerted by the subduction mechanism or removal of overburden. Trench sediments exhibit undercompaction at sub-bottom depths less than 75 meters, becoming normal to overcompacted between 100 and 200 meters. Gas generation within the Trench turbidites, combined with rapid sedimentation, is responsible for the shallow undercompacted unit. On the oceanic Plate, lithologic changes, variable depositional rates, and vertical tectonics appear responsible for differing compaction states.
\end{abstract}

\section{INTRODUCTION}

Gravitational compaction describes the process whereby sediment particles gradually become lithified under increasing overburden pressure to form sedimentary rock (Hedberg, 1936). In this process, there is an "expulsion of pore fluids and pore volume decreases in a sedimentary column as a result of normal and shear-compressional stresses due to the overburden load" (Riecke, III, and Chilingarian, 1974). Skempton (1970) considers "gravitational compaction" and "consolidation" to be nearly synonymous terms and defines consolidation as "the result of all processes causing the progressive transformation of an argillaceous sediment from a soft mud to a clay and finally to a mudstone or shale." Meade (1966) discussed the various parameters (e.g., particle size, surface area, cation-exchange capacities, and sedimentation rates) that affect early-stage compaction, and Hamilton (1976) presented a comprehensive review of the changes in density and porosity of various marine-sediment types with depth.

Compaction is a regular, predictably occurring phenomenon, resulting ultimately in a sedimentary rock. According to Hamilton (1959), lithification begins when the porosity of a compacting mud reaches about $35 \%$, usually between 500 and 600 meters sub-bottom depth. Numerous other studies (Athy, 1930; Weller, 1959; Powers, 1967; Burst, 1969) have presented models for compaction of argillaceous sediments that reveal a predictable regularity in the compaction process.

DSDP Leg 67 provided an opportunity to study the compaction characteristics of sediment cores obtained

\footnotetext{
${ }^{1}$ Aubouin, J., von Huene, R., et al., Init. Repts. DSDP, 67: Washington (U.S. Govt. Printing Office).
}

from a transect across the Guatemalan continental slope, through the Middle America Trench, and onto the converging Cocos Plate (Fig. 1). The generalized lithologies encountered on this transect are shown in Figure 2.

The following questions provided a framework for this investigation:

1) Do the properties of the older sediments differ from the Quaternary sediments? If so, is it possible to infer anything about the geological history of these older sediments from their compaction characteristics?

2) Are there significant differences in compaction between sediments accumulating in adjacent continental margin environments (i.e., oceanic plate, trench, and continental slope)?

3) What are the time-space relationships between convergence processes and compaction characteristics of sediments found at the base of the continental slopetrench margin?

\section{THE ANALYTICAL MODEL}

Because compaction of a sediment is the result of closer particle packing, reduction in pore volume, and increase in bulk density, it should be possible to estimate the state of compaction graphically by plotting any of these parameters against depth. Hamilton (1976) has shown the theoretical relationships of bulk density and porosity with depth for various types of normally compacting marine sediments and has developed equations to predict values of bulk density and porosity at selected depths. Undercompacted sediments should show lower values of bulk density and greater pore volume than predicted, whereas greater values of bulk density and lower pore volume than predicted should be observed in overcompacted sediments.

Inasmuch as changes in volume and density relationships depend ultimately upon overburden pressure, 


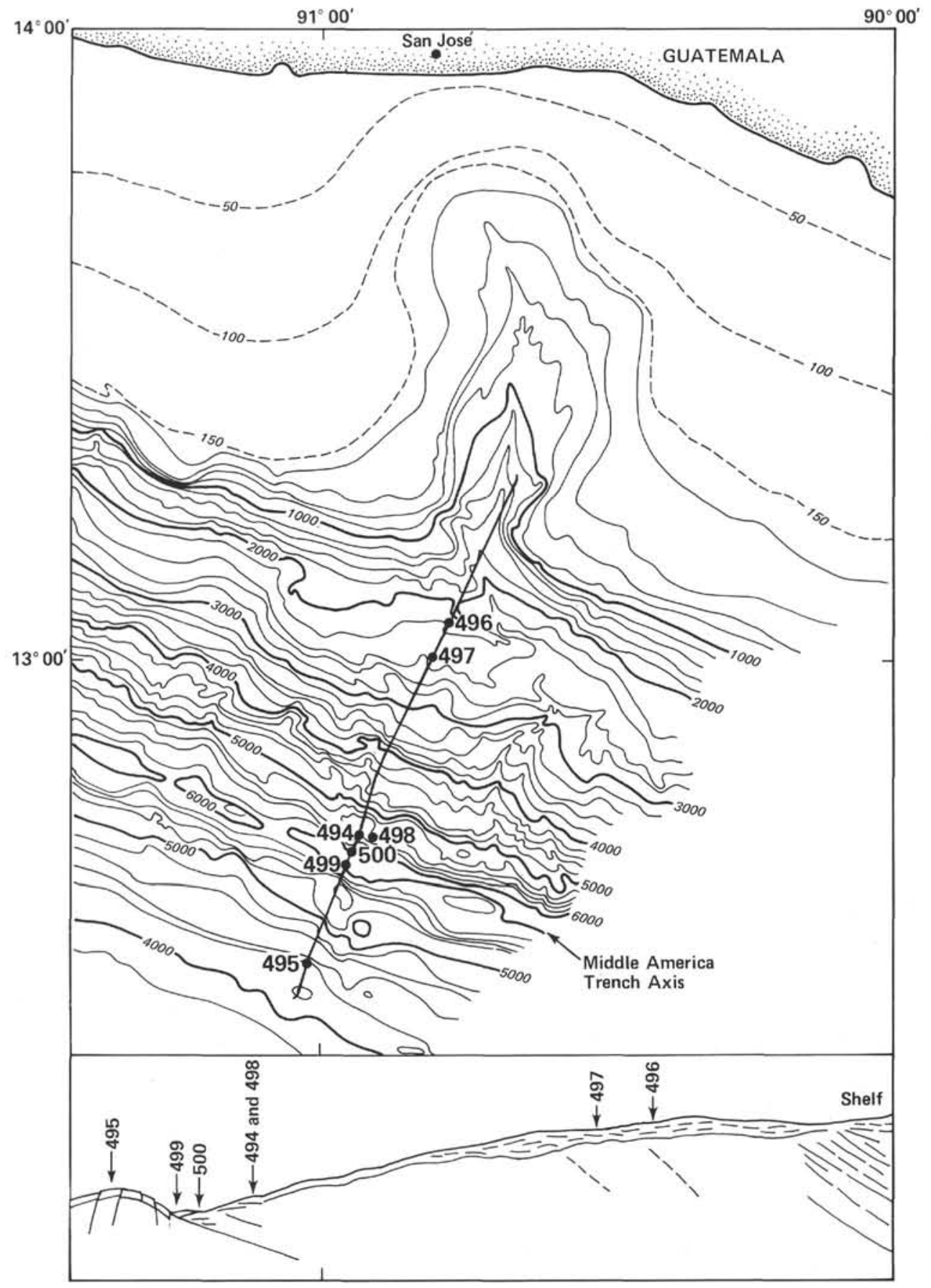

Figure 1. Leg 67 site location map.

graphs relating overburden pressure to depth in the sediment column should also reveal compaction trends. Zones of under- or overcompacted sediments should deviate from the trend established for a normally compacting sediment. (A normally compacting sediment is one in which rate of drainage of interstitial water equals the rate of sediment accumulation, and overburden pressure is only a function of the sediment skeleton-the lithostatic load of Bishop, 1979.)

The problem involves establishing a standard overburden pressure versus depth curve to which the sedi- ments under investigation may be compared. Hamilton (1976) indicates that no universal curve exists for density and porosity, and each section studied will possess its own unique curve, depending upon a number of complex factors, chief of which is lithology. It should be possible, however, to calculate a theoretical compaction curve for each commonly occurring sediment type (for comparison purposes), assuming textural homogeneity throughout the thickness of the sediment column.

Compaction curves for the various types of commonly occurring marine sediments (Fig. 3) were constructed 
* COCOS PLATE $\rightarrow$

495

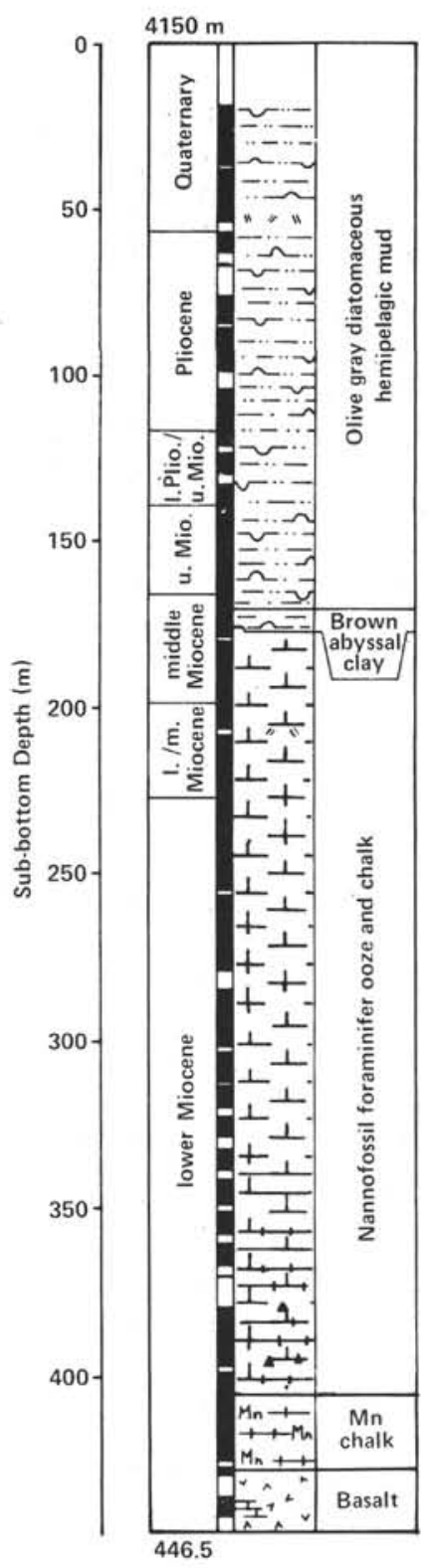

TRENCH

499A

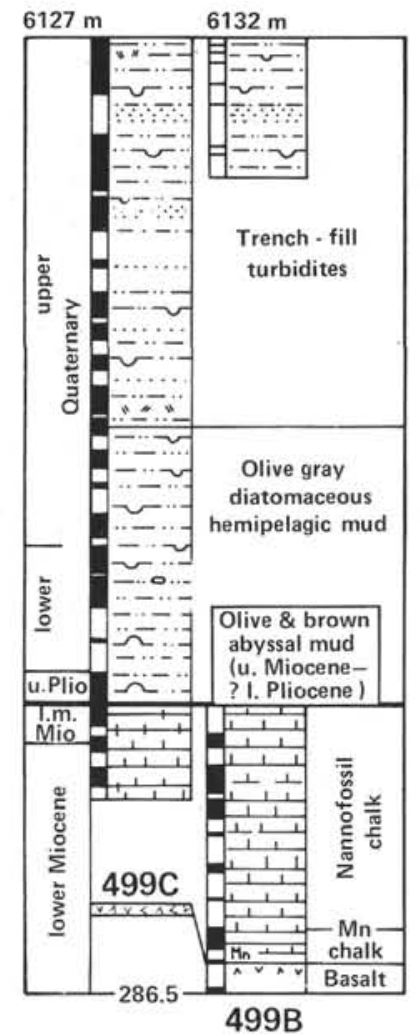

500

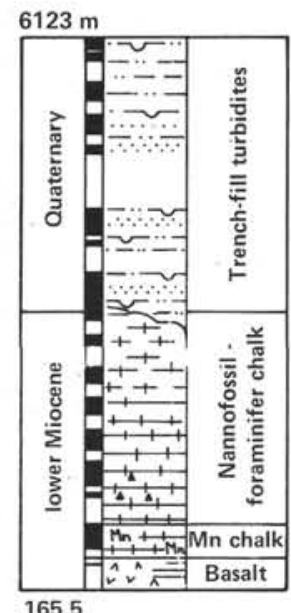

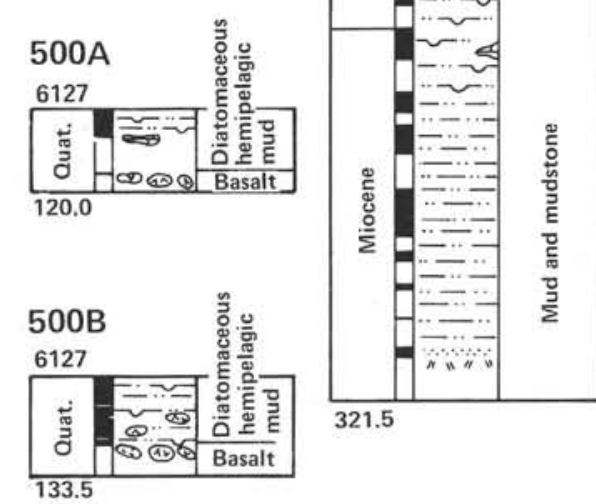

TRENCH SLOPE

$5497 \mathrm{~m}$

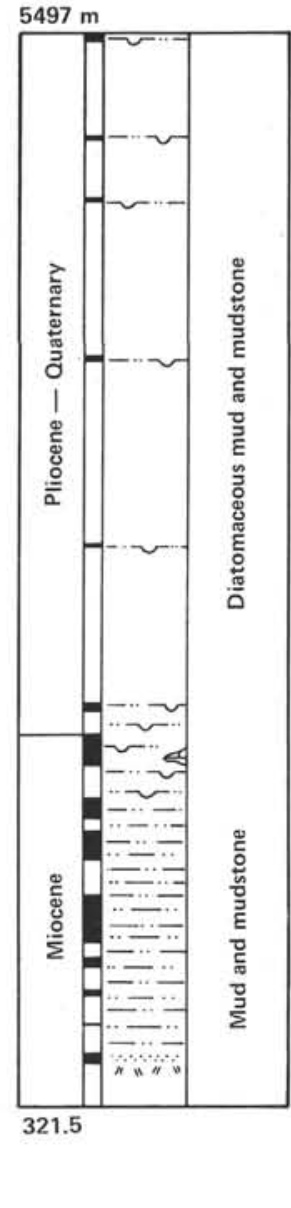

497

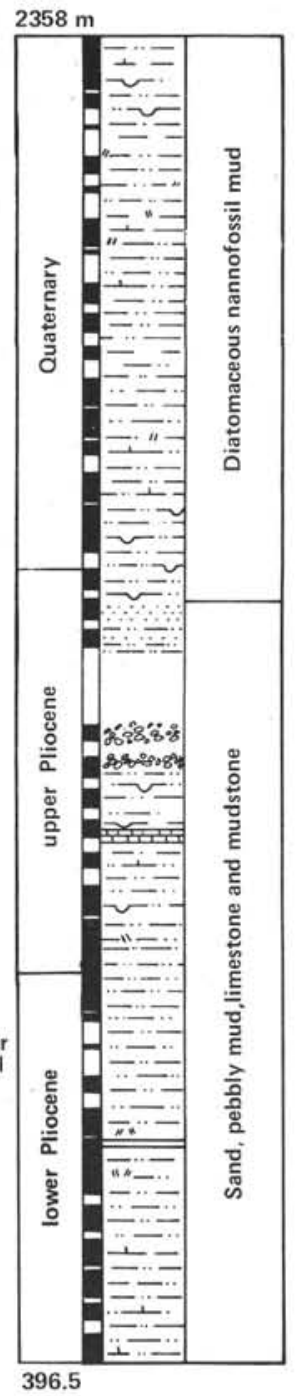

496

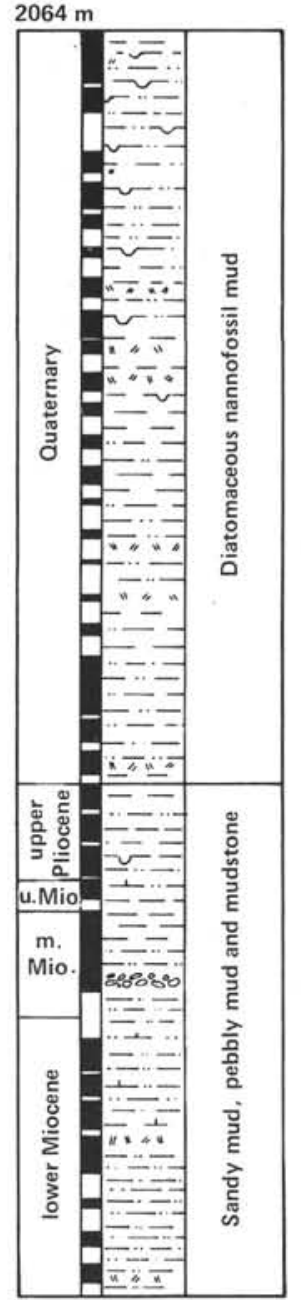




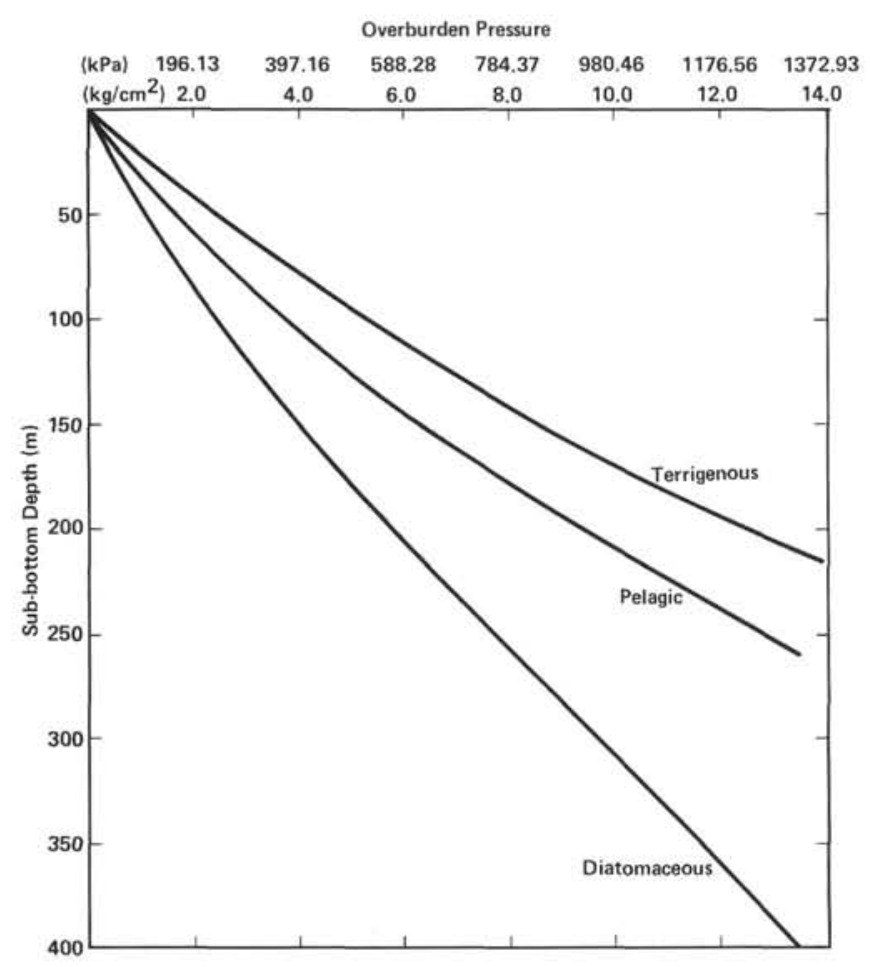

Figure 3. Theoretical compaction curves (after Hamilton, 1960, 1976).

from Hamilton's data $(1960 ; 1976)$. Overburden pressure was calculated according to the following:

$$
\text { Overburden pressure }\left(\bar{\sigma}_{v}\right)=\left(\varrho_{w s}-\varrho_{s w}\right) d
$$

where

$$
\begin{aligned}
\varrho_{w s} & =\text { wet-bulk density of the sediment } \\
\varrho_{s w} & \left.=\text { sea water density (assume } 1.025 \mathrm{~g} / \mathrm{cm}^{3}\right), \text { and } \\
d & =\text { depth increment }(\mathrm{cm})
\end{aligned}
$$

The curves show markedly different profiles, all following the same general pattern. After an initial nearly linear steep slope to about 100 meters, the curves become concave upward as overburden pressure increased with depth. The curves for terrigenous clay, pelagic clay, and diatom ooze exhibit unique profiles. Each shows an increasing response to overburden pressure, with the water-rich biogenic oozes showing lesser increases than the clastic sediments, probably due to slower rates of interstitial water drainage.

The compaction curves for terrigenous sediment and diatomaceous oozes represent the two extremes of expectable marine sediment types. All other types (e.g., diatomaceous muds) lie within the limiting envelope as defined by the upper and lower compaction curves.

Each curve represents a normally compacting specific sediment type; therefore data points for that particular sediment type plotting above the curve could be interpreted as representing overcompaction (i.e., overburden pressure greater than normal), whereas points plotting below the curve could be interpreted as representing undercompaction (i.e., overburden pressure less than normal).

\section{Compressibility}

Skempton (1970) advocated the use of "sedimentation-compression diagrams" to determine the compressibility of sediments. The diagram relates changes in void ratio $(e)$ to increasing overburden pressure $(p)$ and may reveal the compaction history of the sedimentary column. The compressibility of a normally compacted sediment should follow a straight line when plotted on a semilogarithmic scale (e.g., $e \log p$ diagram). Behavior varies with Atterberg limits (i.e., sediments with high liquid limits compress more readily than do lower-liquidlimit sediments). Accordingly, form lines showing the expectable normal compressional behavior for highly plastic clays $\left(w_{L}=140\right)$ and clays of low plasticity $\left(w_{L}\right.$ $=90$ ) are superimposed on the sedimentation-compression diagrams for comparison purposes (Figs. 6, 9, 12, 15,17 , and 20).

Computed overburden pressure and void ratio are determined as previously described.

\section{ANALYTICAL PROCEDURE}

The primary source of data for this study was provided by wet bulk density profiles of the cores retrieved during Leg 67 drilling. Wet bulk density was measured continuously on all cores, using the Gamma Ray Attenuation Porosity Evaluator (GRAPE) (Evans and Cotterell, 1970). Each core was slowly passed through the GRAPE and its bulk density recorded. Prior to each analysis, the GRAPE was calibrated to a distilled water $\left(1.00 \mathrm{Mg} / \mathrm{m}^{3}\right)$ and aluminum $\left(2.60 \mathrm{Mg} / \mathrm{m}^{3}\right)$ standard. GRAPE values are considered to be within $3 \%$ to $5 \%$ of absolute values (Hamilton, 1976).

Water content of selected core samples was measured gravimetrically according to standard techniques. No correction was made for salt content. Atterberg limits were measured following the procedure described by Lambe (1951). Samples were analyzed with their natural water content. Sea water was used when necessary for the liquid limit test.

Shear strength measurements were made at 1-meter intervals using the hand-held TORVANE. All measurements were made on the face of the split core (i.e., perpendicular to bedding).

Void ratio was calculated from GRAPE porosity values through the equation

$$
e=\frac{\eta}{1-\eta}
$$

where

$$
\begin{aligned}
& e=\text { void ratio, } \\
& \eta=\text { porosity. }
\end{aligned}
$$

\section{DATA ANALYSIS}

\section{Site 496}

Quaternary diatomaceous muds extend from the mudline down to 112 meters, changing to nannofossil muds that extend to 225 meters. Sandy muds (middle Miocene through Pliocene) extend to 285 meters and become lithified through the lower Miocene section to the base of the hole (Fig. 4). The compaction curve closely parallels the curve for diatomaceous ooze, thus reflecting the mixed hemipelagic-diatomaceous lithology. A change in slope occurs at 265 meters, coinciding with the middle/upper Miocene boundary and the lithologic change to sandy mud beginning at 225 meters. 


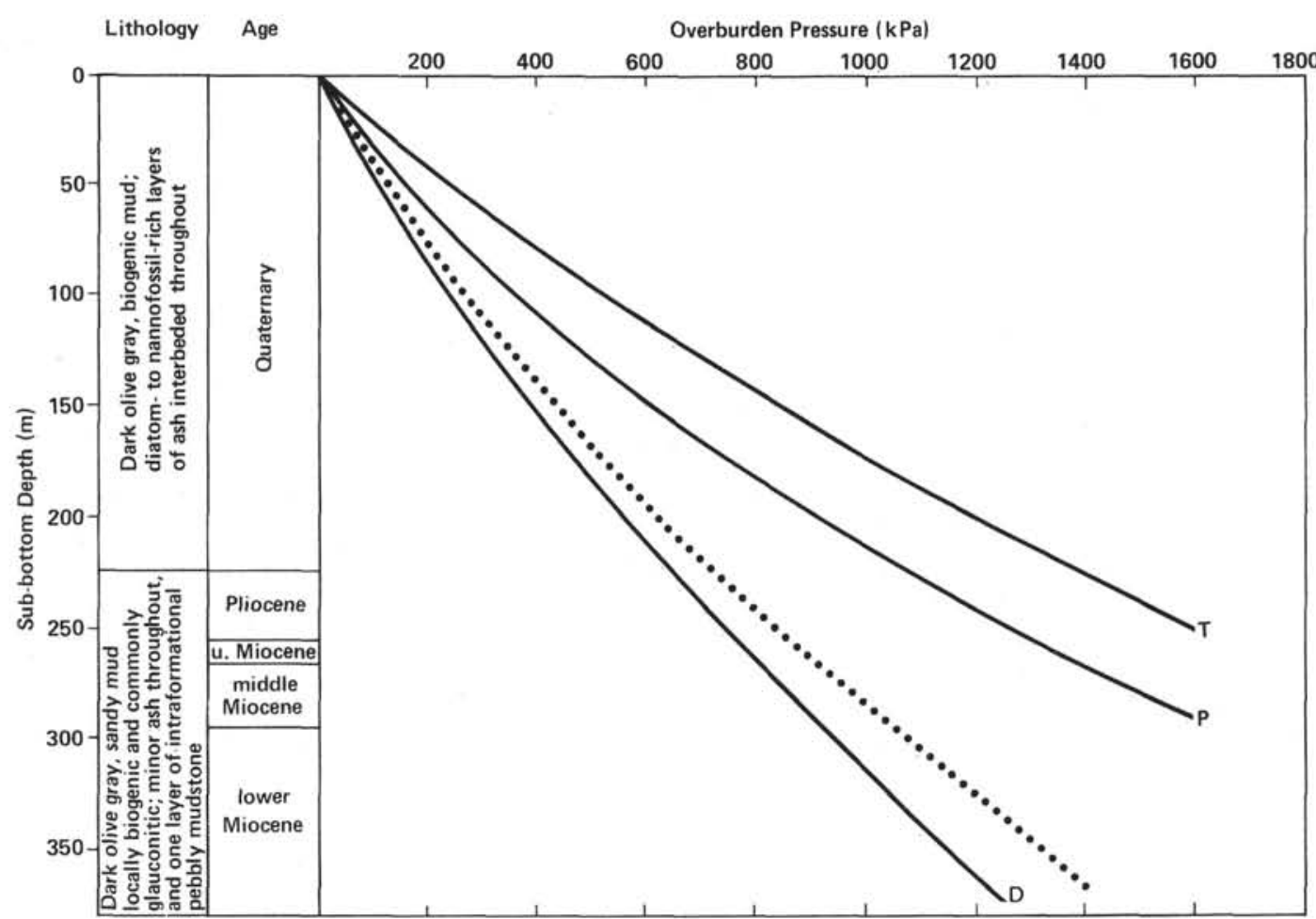

Figure 4. Compaction curve, Site 496. $(\mathrm{T}=$ terrigenous, $\mathrm{P}=$ pelagic, and $\mathrm{D}=$ diatomaceous in Figures $7,10,13,16$, and 19.)

Water content and GRAPE density show only gradual changes to 225 meters, reflecting the lithologic consistency of the Quaternary muds (Fig. 5A, B). Between 225 and 285 meters, an abrupt increase in density (1.55 $\left.\mathrm{Mg} / \mathrm{m}^{3}\right)$ and decrease in water content (60\% dry wt.) correspond with the middle Miocene to Pliocene sandy muds. Lithification of the lower Miocene sandy mudstone is recognized by the abrupt increase in GRAPE density to $1.65 \mathrm{Mg} / \mathrm{m}^{3}$ and decrease in water content to $35 \%$ dry weight.

Shear strength (Fig. 5C) remains low through the upper 100 meters of the Quaternary sediments, increasing gradually through the remainder of the sediment column. Considerable variation is observed in the Pliocene and older sediments.

The sediments appear highly compressible (Fig. 6), following the form line established by Skempton (1970) for sediments possessing high liquid limit. Undercompaction is indicated between $2.0(196.1 \mathrm{kPa})$ and 8.0 $(784.5 \mathrm{kPa}) \mathrm{kg} / \mathrm{cm}^{2}$ overburden pressure, as the majority of data points lies to the right of the $w_{L}=140$ form line, showing greater void ratios than predicted. At overburden pressures greater than $8.6 \mathrm{~kg} / \mathrm{cm}^{2}(843.3$ $\mathrm{kPa}$ ), the void ratio decreases abruptly in overcompacted Pliocene and lower and middle Miocene mudstones.

\section{Site 497}

The compaction curve (Fig. 7) shows several changes in slope, which may result from lithologic variation and differing compaction states. From the mudline down to 50 meters, the compaction curve follows the curve for terrigenous sediments and may result from a lithology dominated by terrigenous components. The curve shifts toward pelagic sediments, crossing the pelagic sediments curve at 160 meters. This shift corresponds with a lithologic change from biogenic mud to sandy and pebbly mud. The section from 60 to 160 meters is interpreted to be undercompacted, because the compaction curve (if controlled by lithology alone) should closely follow the curve for terrigenous sediments.

Lithification begins in the upper Pliocene mudstones at 225 meters, and compaction (Fig. 7) resumes following a smooth curve characteristic of a mixed biogenicterrigenous lithology.

GRAPE density (Fig. 8B) increases gradually, from $1.43 \mathrm{Mg} / \mathrm{m}^{3}$ to $1.55 \mathrm{Mg} / \mathrm{m}^{3}$ at 148 meters, then abruptly decreases through the interval from 148 to 215 meters. Water content (Fig. 8A) follows a similar, but inverse pattern. Density increases gradually, with some variation, to 270 meters, where it remains relatively constant at $1.60 \mathrm{Mg} / \mathrm{m}^{3}$ through the lithified section beginning at 270 meters to the base of the hole.

Shear strength (Fig. 8C) shows a unit of low strength sediment extending from the mudline down to $85 \mathrm{me}-$ ters. It increases gradually to a maximum at 150 meters, remaining relatively constant to 270 meters. A four-fold increase in shear strength occurs in the lithified sediments below 270 meters.

Compressibility is quite high; void ratios are greater than those at Site 496 at equivalent overburden pressures (Fig. 9). These sediments have an average liquid limit of $118 \%$ and are classified as $\mathrm{CH}$ soils (inorganic 


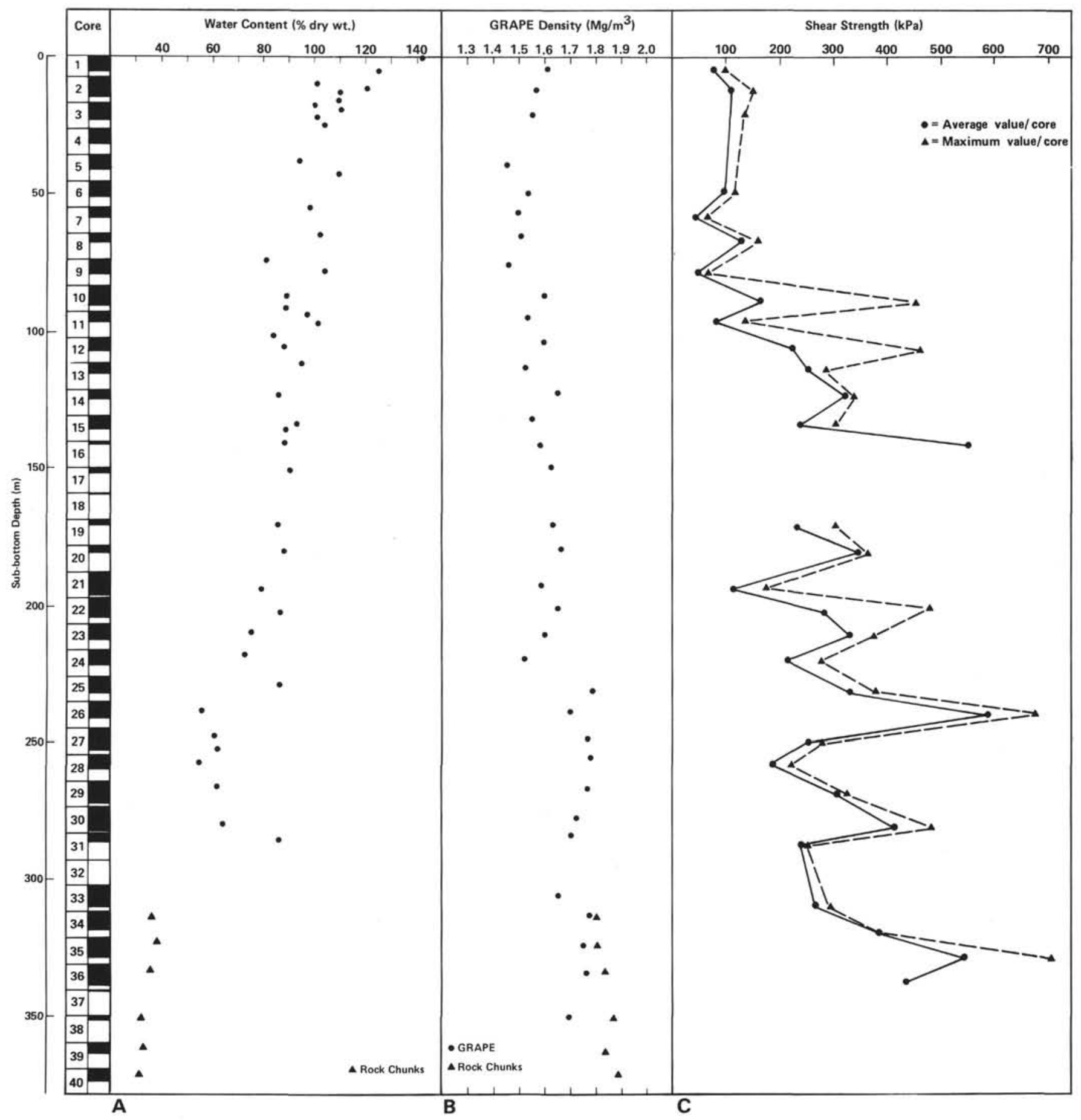

Figure 5. A. Water content, Site 496. B. GRAPE density, Site 496. C. Shear strength, Site 496.

clays of medium to high plasticity) (Faas, this volume). As such they should lie slightly to the left of the form line for $w_{L}=140$. The entire section appears to be undercompacted, extending through Pliocene sandy mud.

\section{Site 494}

The Quaternary section is dominated by diatomaceous mud extending to 125 meters into Pleistocene sediments. Mud and mudstone extend from 125 meters through the
Miocene at 225 meters. Lithification occurs at shallow depths $(50 \mathrm{~m})$.

The compaction curve (Fig. 10) initially follows a slope between terrigenous and pelagic sediments, curving upward at 50 meters to follow the curve for terrigenous sediments to 125 meters. Below 125 meters the curve changes slope and follows that of a lower-density sediment. GRAPE density increases gradually to 275 meters, below which a sharp increase occurs, associated 


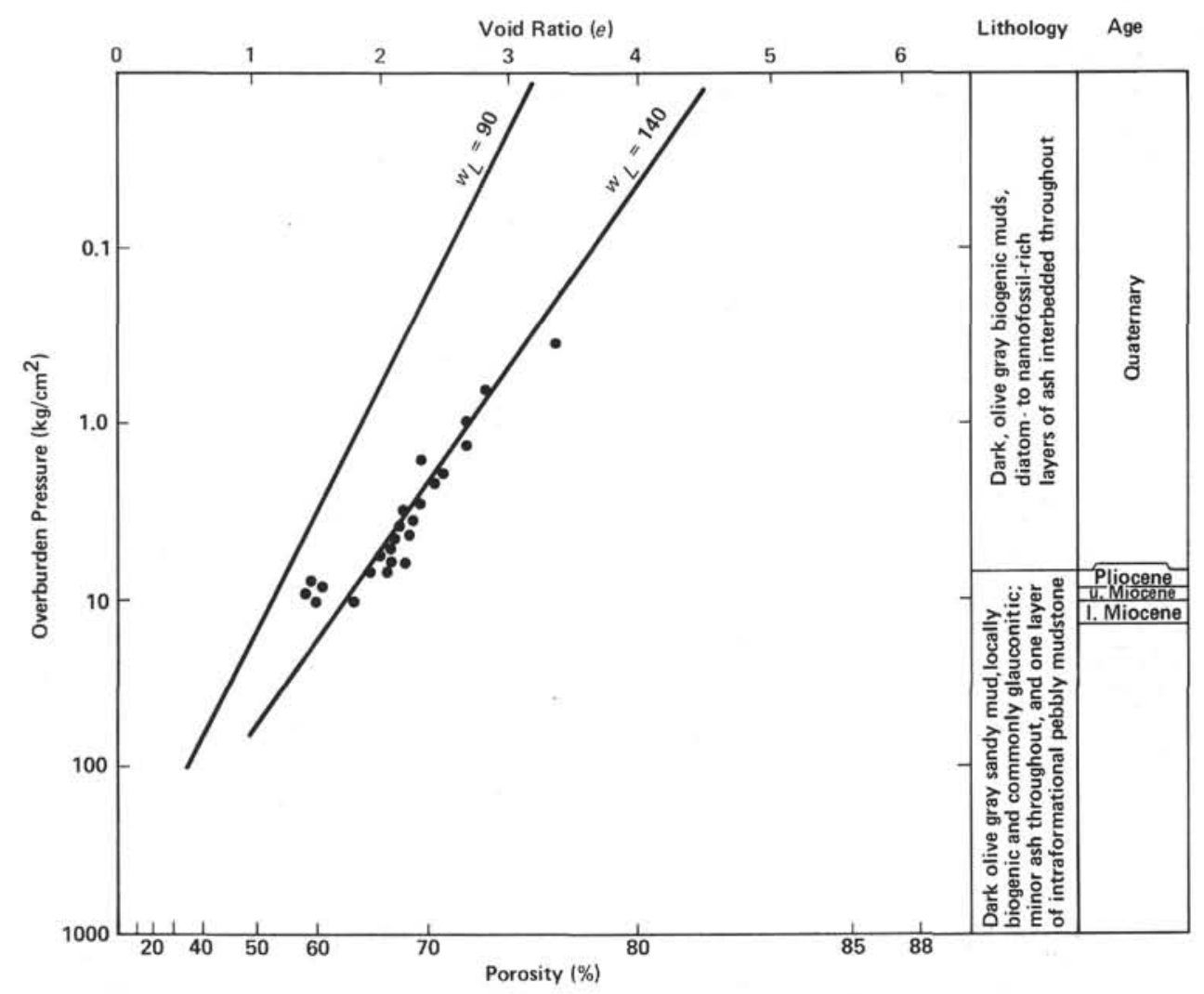

Figure 6. Sedimentation-compression diagram, Site 496.

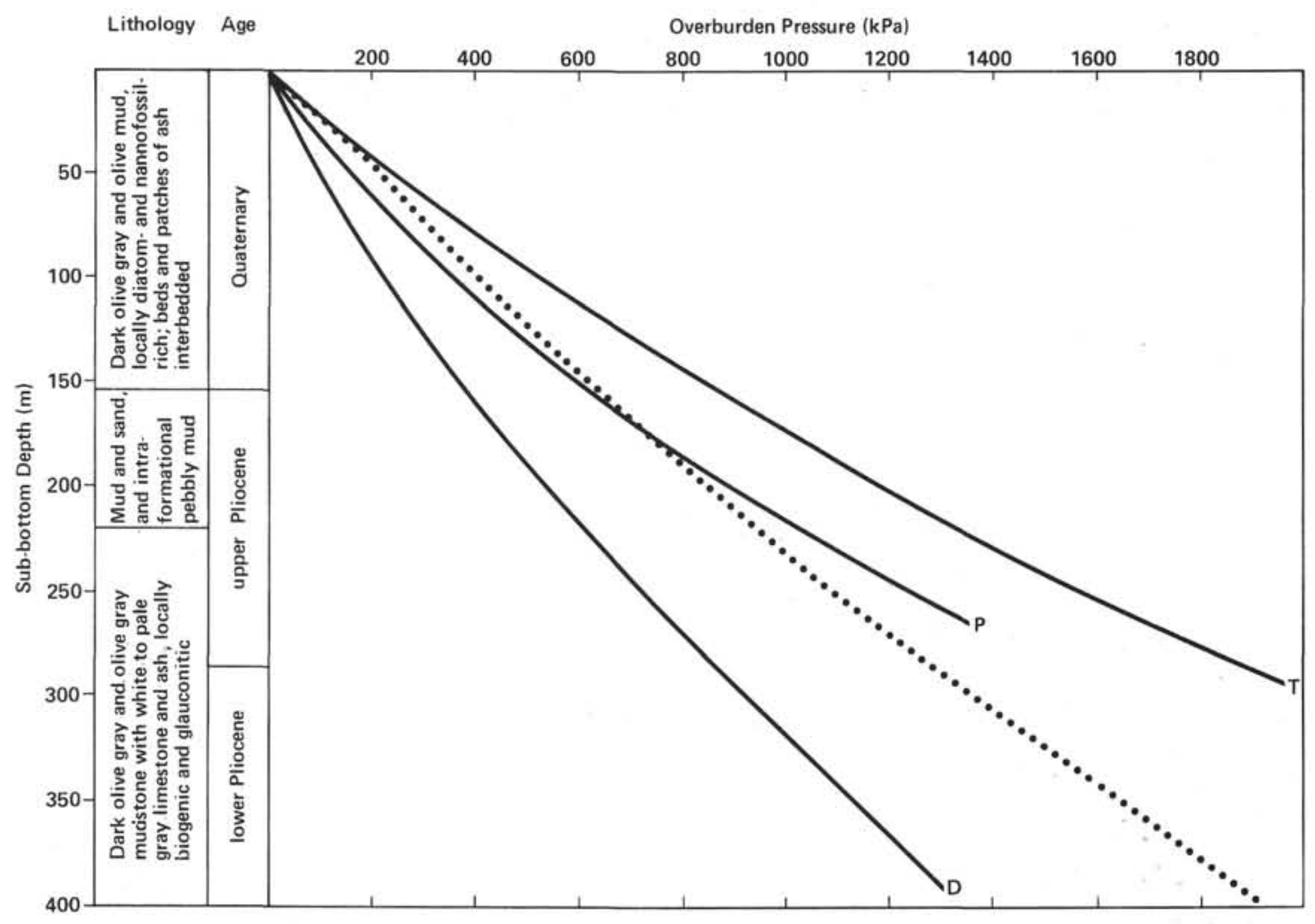

Figure 7. Compaction curve, Site 497. 


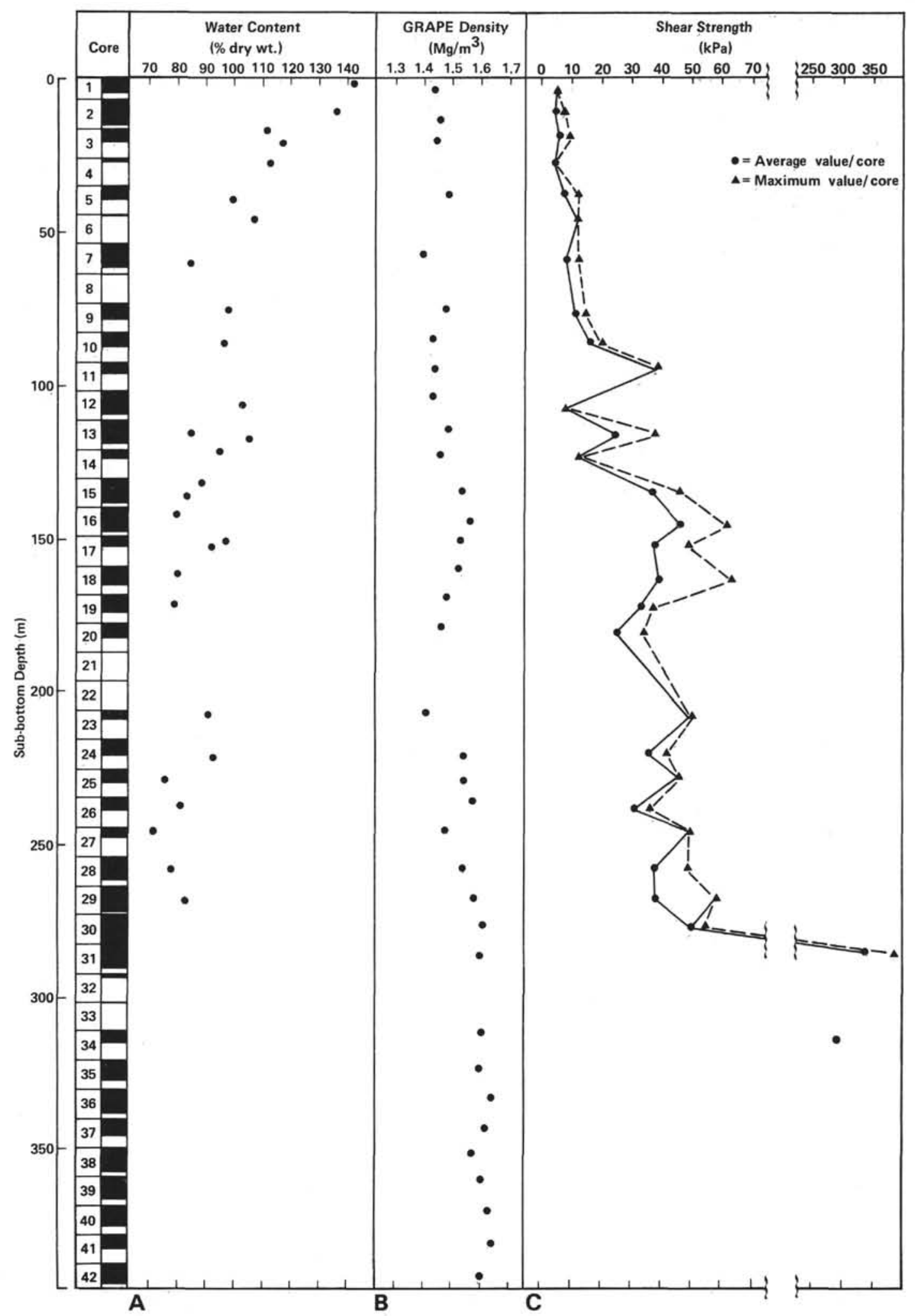

Figure 8. A. Water content, Site 497. B. GRAPE density, Site 497. C. Shear strength, Site 497. 


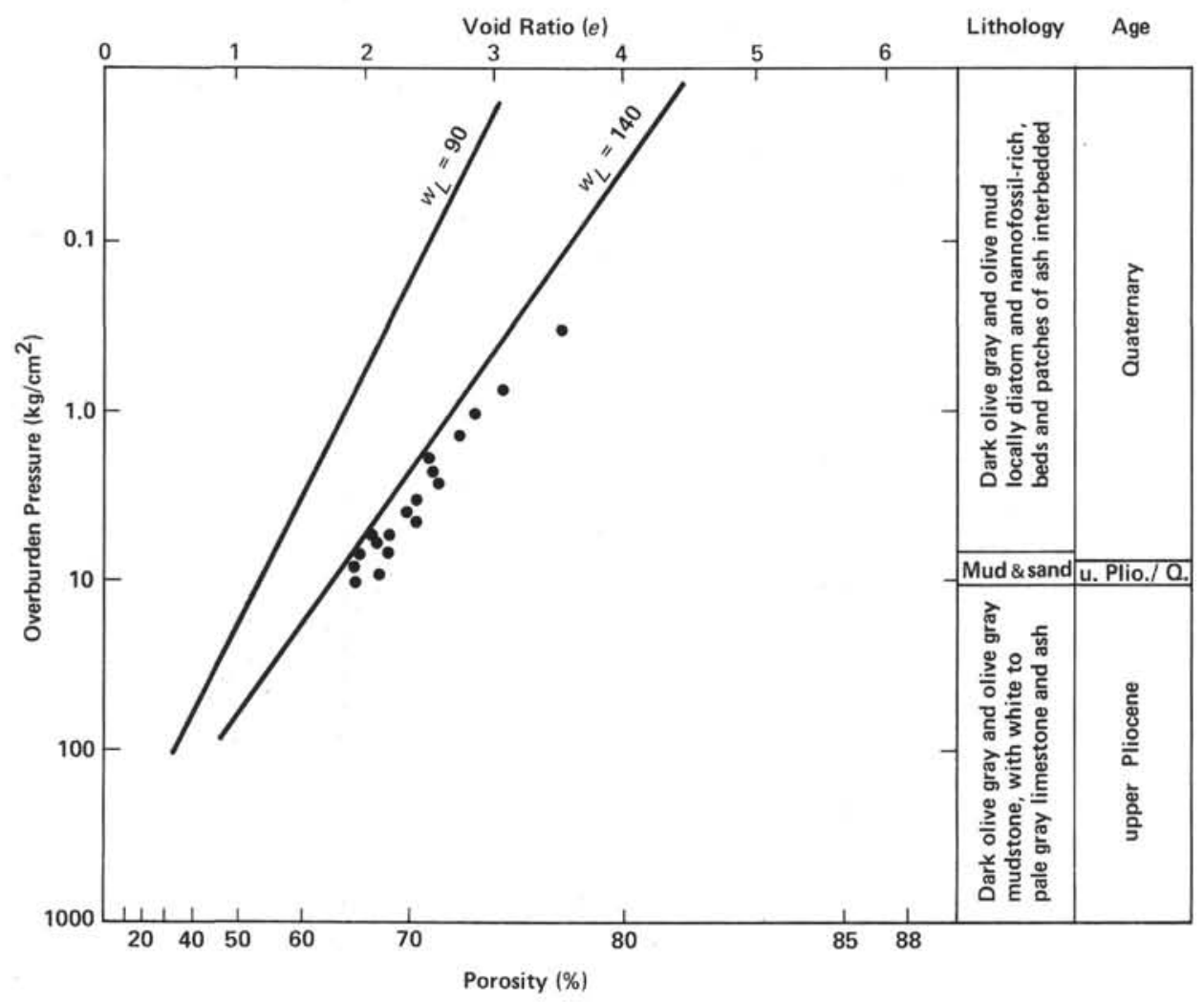

Figure 9. Sedimentation-compression diagram, Site 497.

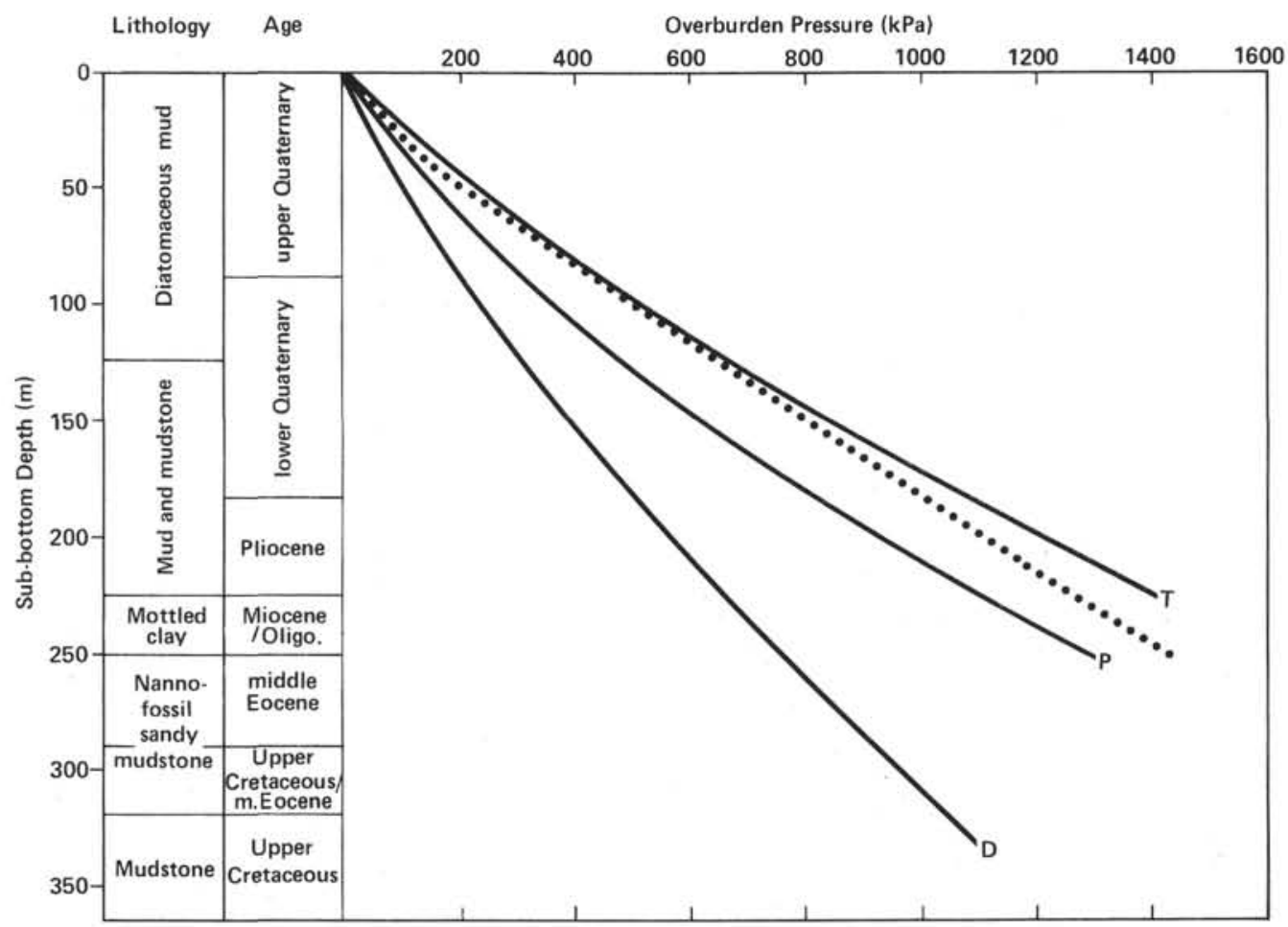

Figure 10. Compaction curve, Site 494. 
with nannofossil limestones (Fig. 11B). Water content generally decreases throughout the sediment column (Fig. 11A).

Shear strength remains low until 25 meters, where it increases abruptly, corresponding to the increase in lithification of the diatomaceous mudstones (Fig. 11C).

Three distinctly different compressibility states are shown (Fig. 12). Highly compressible upper Quaternary silty-sandy mud occurs from the mudline to 46 meters, corresponding to an overburden pressure of $1.5 \mathrm{~kg} / \mathrm{cm}^{2}$ $(147.0 \mathrm{kPa})$. These data points follow exactly Skempton's (1970) form line for normally compacting, highliquid-limit sediments. Quaternary silty-sandy mud and Pleistocene mudstones and diatomaceous claystones-siltstones occur between 46 and 170 meters and show decreased compressiblity (overcompaction) between 1.5 $(147.0 \mathrm{kPa})$ and $10 \mathrm{~kg} / \mathrm{cm}^{2}(980.6 \mathrm{kPa})$ overburden pressure. From 170 to 240 meters, Pleistocene and Pliocene claystones show low compressibility between 10 $(980.6 \mathrm{kPa})$ and $20 \mathrm{~kg} / \mathrm{cm}^{2}(1961.3 \mathrm{kPa})$ and are highly compacted. Each of the observed trends in Figure 12 follows the changes in slope of the overburden pressure (Fig. 10).

\section{Site 499}

The upper Quaternary consists of trench-filling sediments, primarily biogenic muds alternating with turbidite sands. The lower sediments are hemipelagic diatomaceous muds to 200 meters. Chalks occur below 200 meters in lower Pliocene sediments. The compaction curve (Fig. 13) follows that of diatom ooze to 35 meters, then turns sharply upward and parallels the curve of a terrestrial sediment to 150 meters. Below this depth, the compaction curve suggests a change in lithology to pelagic sediments, beginning in the lower Quaternary and extending into the lower Miocene.

Figure 14B indicates a unit of low bulk density (diatom mud) extending from the mudline to 33 meters. The turbidites (33-125 m) contain shallow-water fossils and wood fragments. Geophysical records show localized regions where reflections pass laterally into diffuse zones, indicating an abundance of gas in the sediments. Methane content of the sediments is quite high $(65-75 \%)$, suggesting that microbial decomposition of organic matter is responsible for their gassy nature. GRAPE density shows unusual variability; shear strength is low (10-15 $\mathrm{kPa}$ ), and the interval is believed to be undercompacted. The hemipelagic diatomaceous muds (125-200 m) represent a change toward lower-density sediments, as expressed by the compaction curve (Fig. 13) and the GRAPE density profile (Fig. 14B). Water content increases significantly through the interval (Fig. 14A), but shear strength remains relatively constant at $30 \mathrm{kPa}$ (Fig. 14C). Lithified lower Miocene chalks occur at 200 meters and show an abrupt increase in GRAPE density (Fig. 14B) and a decrease in water content (Fig. 14A). The interval between 125 and 200 meters, confined as it is between units of greater density above and below, is interpreted to be undercompacted, with excess pore pressure due to high water contents, retarding the development of a normal density profile.
The sedimentation-compression diagram (Fig. 15) shows a unit of high compressibility extending from the mudline to 40 meters $\left(1.9 \mathrm{~kg} / \mathrm{cm}^{2}, 186.3 \mathrm{kPa}\right)$ becoming less compressive from 40 to 80 meters $\left(4.0 \mathrm{~kg} / \mathrm{cm}^{2}\right.$, $392.3 \mathrm{kPa}$ ).

Void ratio reduction follows the normal trend established by Skempton (1970) for high-liquid-limit clays (Site 499 sediments average 111.6\%) (Faas, this volume). Void ratios become erratic through the overburden pressure interval of $4 \mathrm{~kg} / \mathrm{cm}^{2}(392.3 \mathrm{kPa})$ to $4.9 \mathrm{~kg} /$ $\mathrm{cm}^{2}(480.5 \mathrm{kPa})-\mathrm{a}$ section of mixed mud and sand turbidites $(80-125 \mathrm{~m})$ - and increase sharply through the pressure interval from $4.9 \mathrm{~kg} / \mathrm{cm}^{2}(480.5 \mathrm{kPa})$ to 9.0 $\mathrm{kg} / \mathrm{cm}^{2}(882.6 \mathrm{kPa})$, consisting of water-rich siliceous and calcareous, pelagic biogenic muds (125-190 m), which become chalk at 200 meters.

\section{Site $\mathbf{5 0 0}$}

Diatomaceous mud extends from the mudline down to 24 meters, followed by turbidites and interbedded diatom muds, which extend to the base of the Quaternary at 82.5 meters. Lower Miocene foraminifer-nannofossil muds extend from 82.5 to 106 meters, where lithification begins. Basalt is encountered at 156.5 meters.

The compaction curve (Fig. 16) follows the curve of a diatom ooze to 30 meters, then reverses toward the terrigenous sediment compaction curve as terrigenous turbidite sands and muds mix with the lower-density sediment. The compaction curve follows that of pelagic sediments to 105 meters, where lithification begins. The effect of lithification of the lower Miocene chalks shifts the compaction curve toward that of the higher-density terrigenous sediment curve. Consequently, the lithified lower Miocene chalks appear overcompacted. The upper 30 meters appear undercompacted; normally compacted sediments occur between 30 and 106 meters.

Figure 17 shows high compressibility in the undercompacted section from the mudline down to 30 meters. Between 30 and 75 meters, the section appears overcompacted. Between the pressure interval of $2.9 \mathrm{~kg} / \mathrm{cm}^{2}$ $(284.5 \mathrm{kPa})$ to $5.1 \mathrm{~kg} / \mathrm{cm}^{2}(500.1 \mathrm{kPa})(75-106 \mathrm{~m})$, the void ratio decreases along the high-liquid-limit $\left(w_{L}=\right.$ 140 ) trend for normally compacted sediments (Skempton, 1970). At overburden pressures greater than 5.1 $\mathrm{kg} / \mathrm{cm}^{2}(500.1 \mathrm{kPa})$, the void ratio decreases abruptly, coinciding with lower Miocene foraminiferal-nannofossil chalk that extends to the base of Hole 500. This interval is considered to be overcompacted as a result of lithification.

\section{Site 495}

Extending from the mudline down to 172 meters, diatomaceous muds include Pleistocene, Pliocene, and upper Miocene deposits. A thin unit of brown clay $(8 \mathrm{~m})$ occurs at the top of the middle Miocene section, changing to a carbonate ooze-chalk at 180 meters, which becomes lithified below 180 meters and extends through the remainder of the hole.

GRAPE density is high in the upper 50 meters (avg. $1.48 \mathrm{Mg} / \mathrm{m}^{3}$ ) and decreases abruptly to $1.3 \mathrm{Mg} / \mathrm{m}^{3}$ in a unit that extends to 175 meters. This is followed by a 


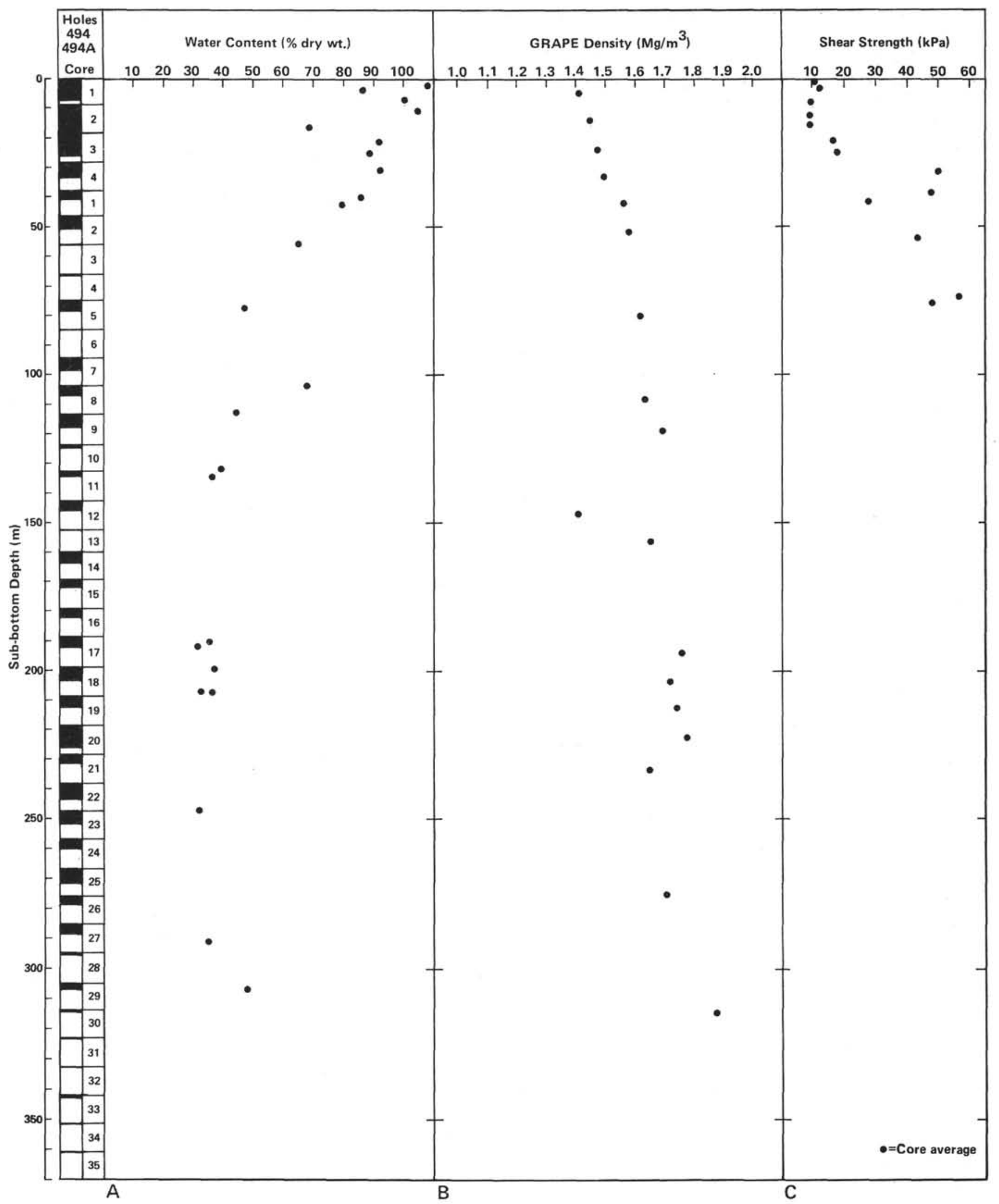

Figure 11. A. Water content, Site 494. B. GRAPE density, Site 494. C. Shear strength, Site 494. 


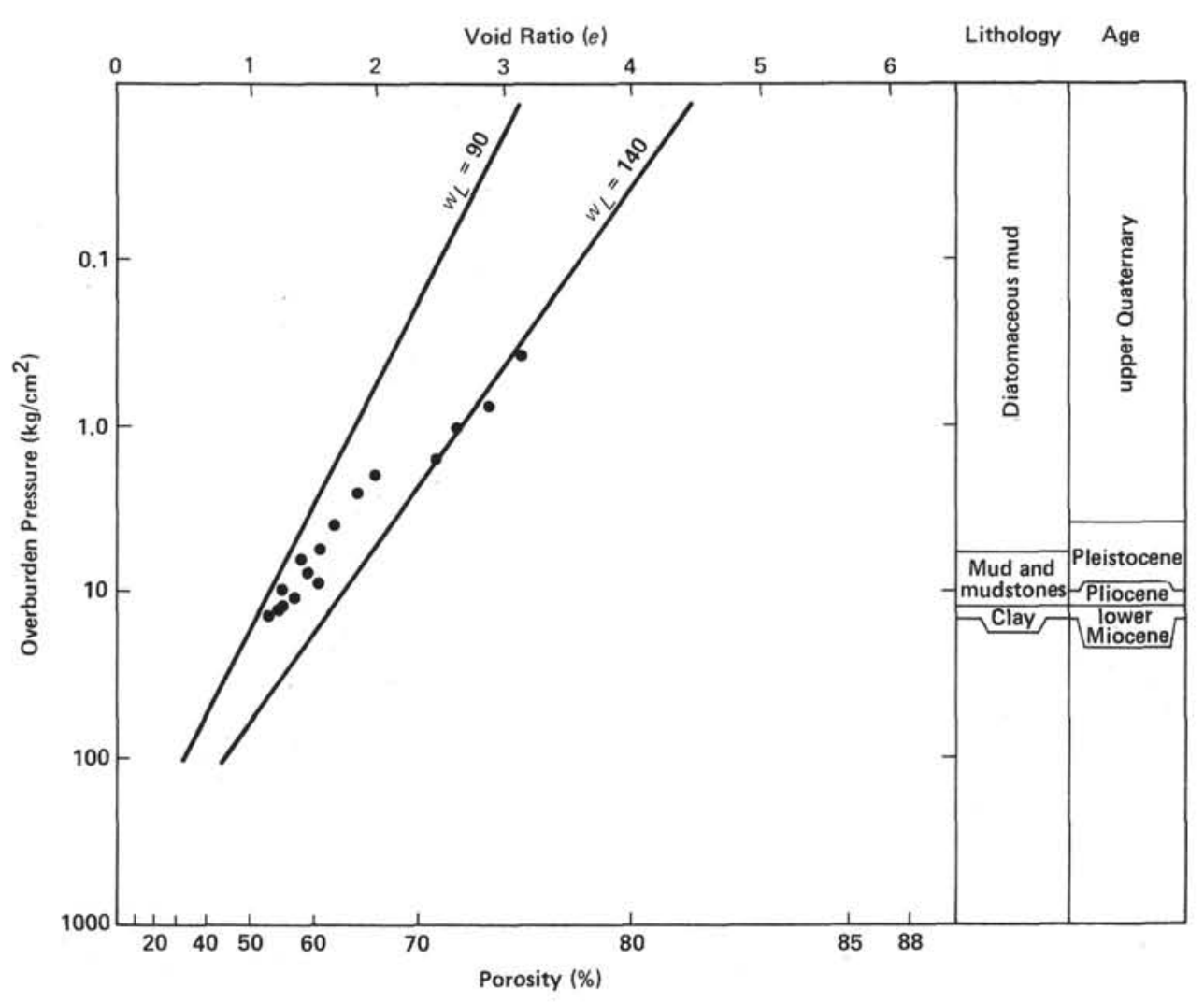

Figure 12. Sedimentation/compression diagram, Site 494.

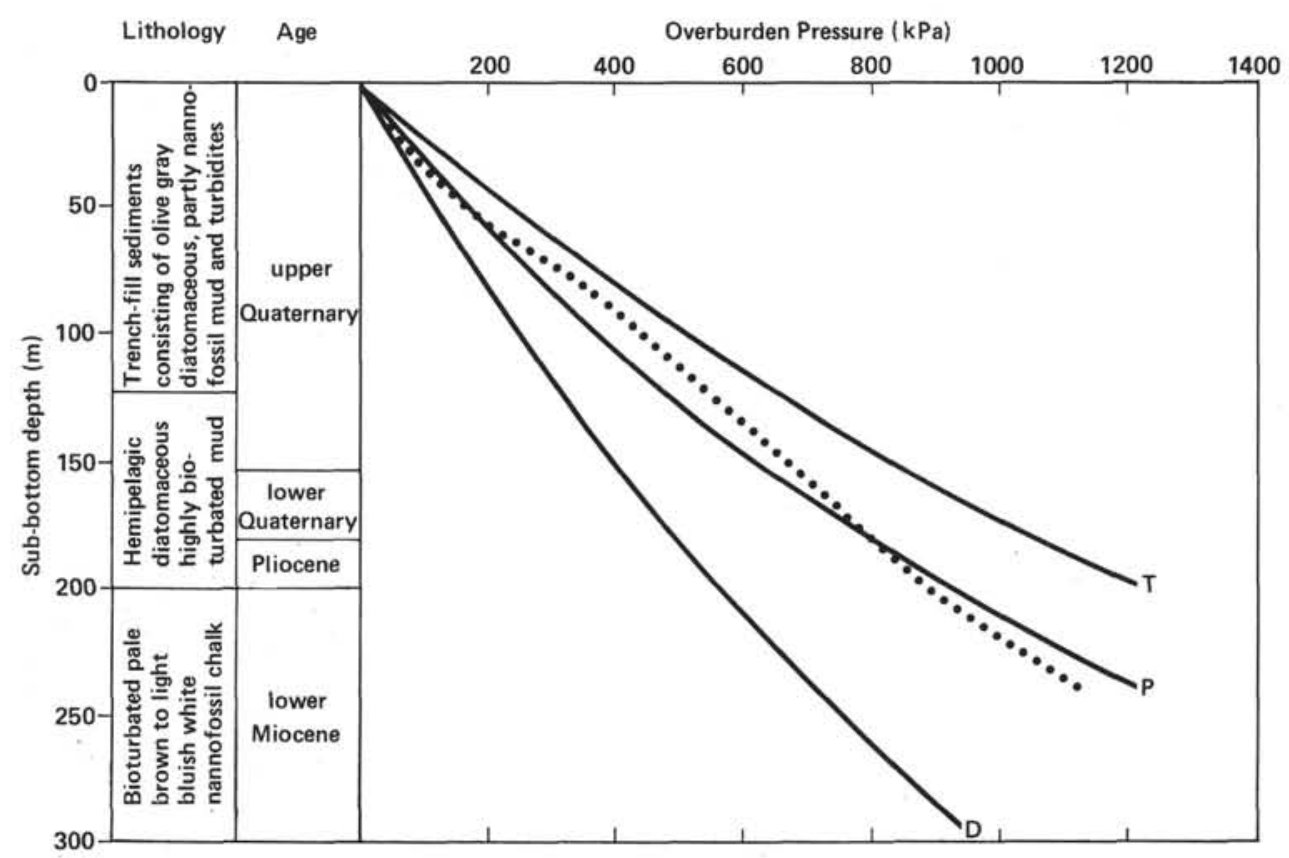

Figure 13. Compaction curve, Site 499.

sharp increase to $1.6 \mathrm{Mg} / \mathrm{m}^{3}$, and then a gradual increase to the base of the hole (Fig. 18B). Water content remains high to 170 meters, then sharply decreases to $80 \%$ (dry wt.) as far as 260 meters, where measurements were discontinued (Fig. 18A). Shear strength averaged $0.12 \mathrm{~kg} / \mathrm{cm}^{2}$ (11.8 $\mathrm{kPa}$ ) (Fig. 18C), unit weight remained nearly constant at $1.43 \mathrm{Mg} / \mathrm{cm}^{3}$, and water content and porosity averaged $135.4 \%$ and $79.7 \%$, respectively.

The compaction curve (Fig. 19) initially follows that of a terrigenous sediment to the base of the Pleistocene at 65 meters. Undercompaction begins at 75 meters and continues to 185 meters. Shear strength increases abrupt- 


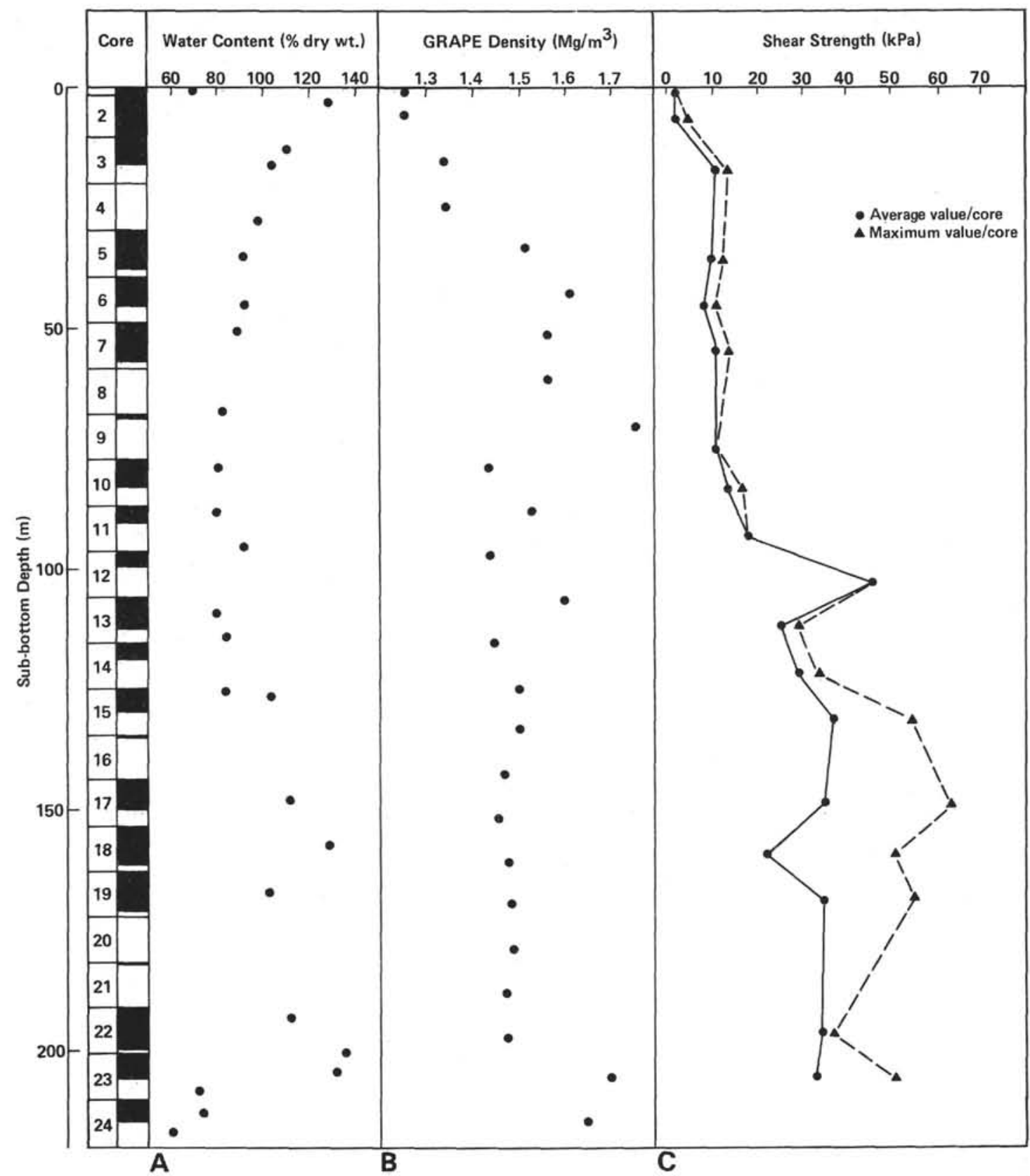

Figure 14. A. Water content, Site 499. B. GRAPE density, Site 499. C. Shear strength, Site 499.

ly, averaging $0.25 \mathrm{~kg} / \mathrm{cm}^{2}$ (24.5 kPa) (Fig. 18C). Anomalously high water contents and low unit weights occur, averaging $188.5 \%$ and $1.35 \mathrm{Mg} / \mathrm{m}^{3}$, respectively (Fig. $18 \mathrm{~A}$ and $\mathrm{B})$. These sediments are Miocene to upper Pliocene hemipelagic diatomaceous silty clays and radiolarian and nannofossil oozes.

Below 190 meters the rate of increase of overburden pressure increases significantly, causing a sharp decrease in the slope of the compaction curve. Lithification has begun at this level and the sediments have become chalk. Unit weight abruptly increases to an average of $1.60 \mathrm{Mg} / \mathrm{m}^{3}$, with corresponding lower water content, averaging $84.4 \%$. Shear strength increases through this interval, averaging $0.30 \mathrm{~kg} / \mathrm{cm}^{2}(29.4 \mathrm{kPa})$ (Fig. 18C).

Figure 20 shows the effects of the different lithologies as they compress under increasing overburden pressure. Void ratios in the uppermost highly compressible hemipelagic sediments fall between 4.0 and 3.2 as overburden pressure increases from $1.0(98.0 \mathrm{kPa})$ to $2.5 \mathrm{~kg} / \mathrm{cm}^{2}$ $(245.1 \mathrm{kPa})$. The various pelagic oozes show a reversal of the void ratio, increasing from 4.0 to greater than 5.0 as overburden increases from $2.5(245.1 \mathrm{kPa})$ to 6.3 $\mathrm{kg} / \mathrm{cm}^{2}(619.8 \mathrm{kPa})$, suggesting that the interval is undercompacted and the cavities and pore spaces are filled 


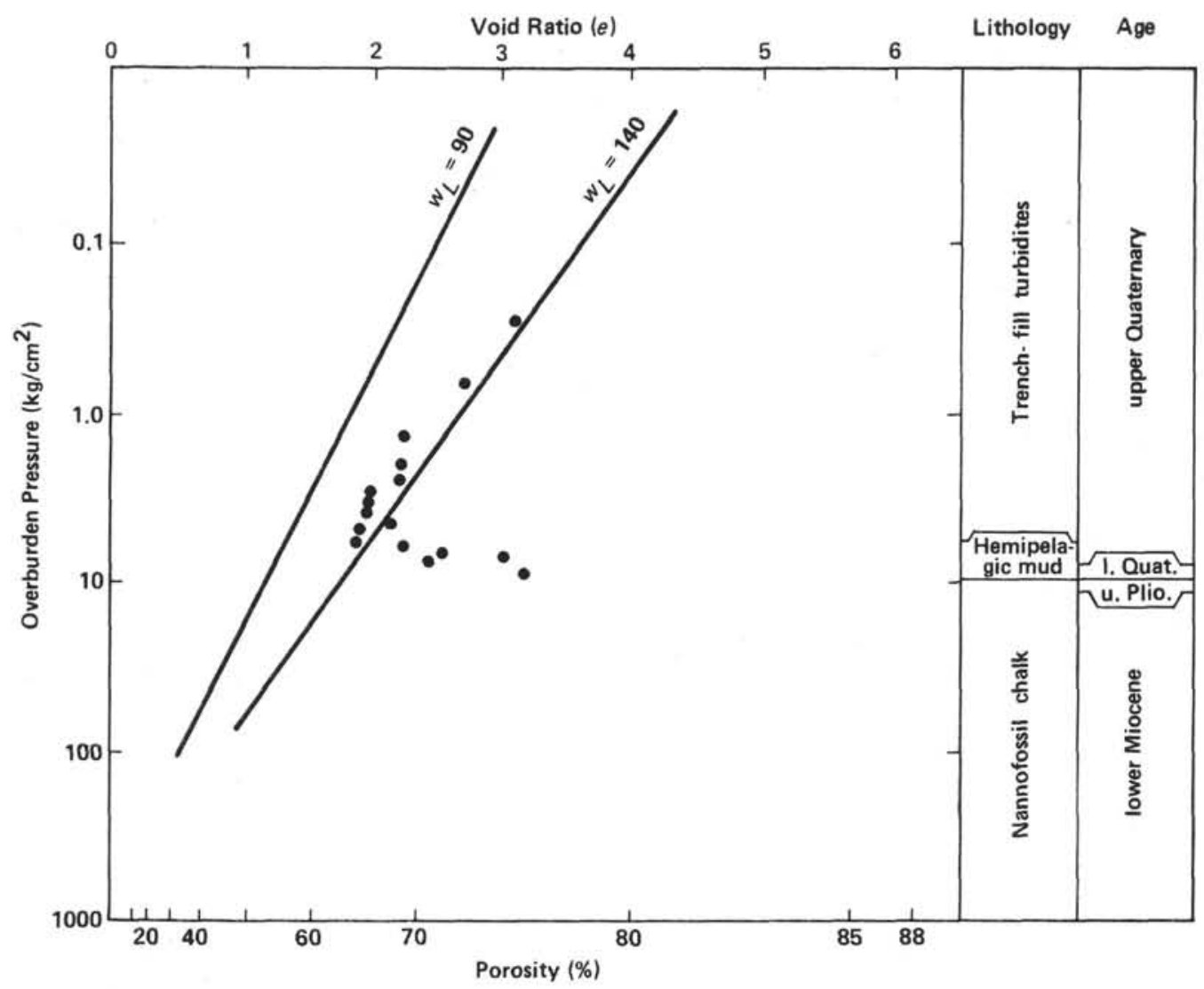

Figure 15. Sedimentation-compression diagram, Site 499.

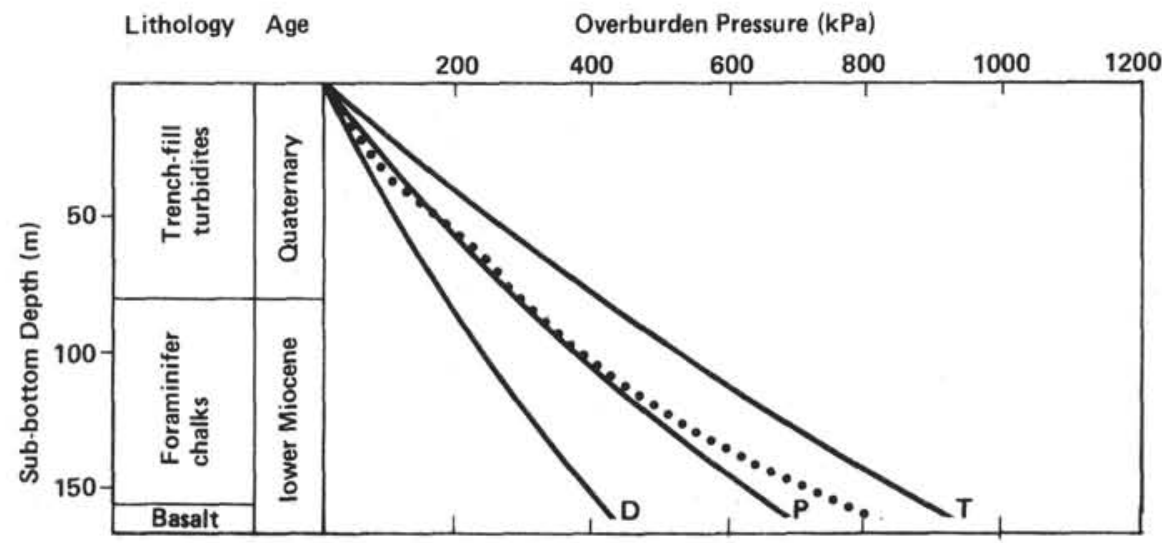

Figure 16. Compaction curve, Site 500.

with water supporting the increased overburden. This condition exists to overburden pressures of $6.5 \mathrm{~kg} / \mathrm{cm}^{2}$ $(637.4 \mathrm{kPa})$. Lithification begins at 172 meters, and the void ratio decreases abruptly to 2.5 , indicating the development of a rigid framework.

\section{DISCUSSION}

\section{Factors Affecting Compaction}

Different forms of compaction are shown within the sediments penetrated on a transect down the Guate- malan continental slope, across the Middle America Trench, and onto the Cocos Plate. Factors responsible for these different compaction states are (1) variation in physical properties associated with lithology; (2) sedimentation rate; (3) tectonic setting; and (4) gases that may be either generated in situ through bacterial processes or related to gas hydrate decomposition. Certain sedimentary sections are dominated by specific lithologies (e.g., siliceous oozes) that behave quite differently under overburden stresses than other sections (e.g., hemipelagic sandy muds) (Hamilton, 1976). Low rates 


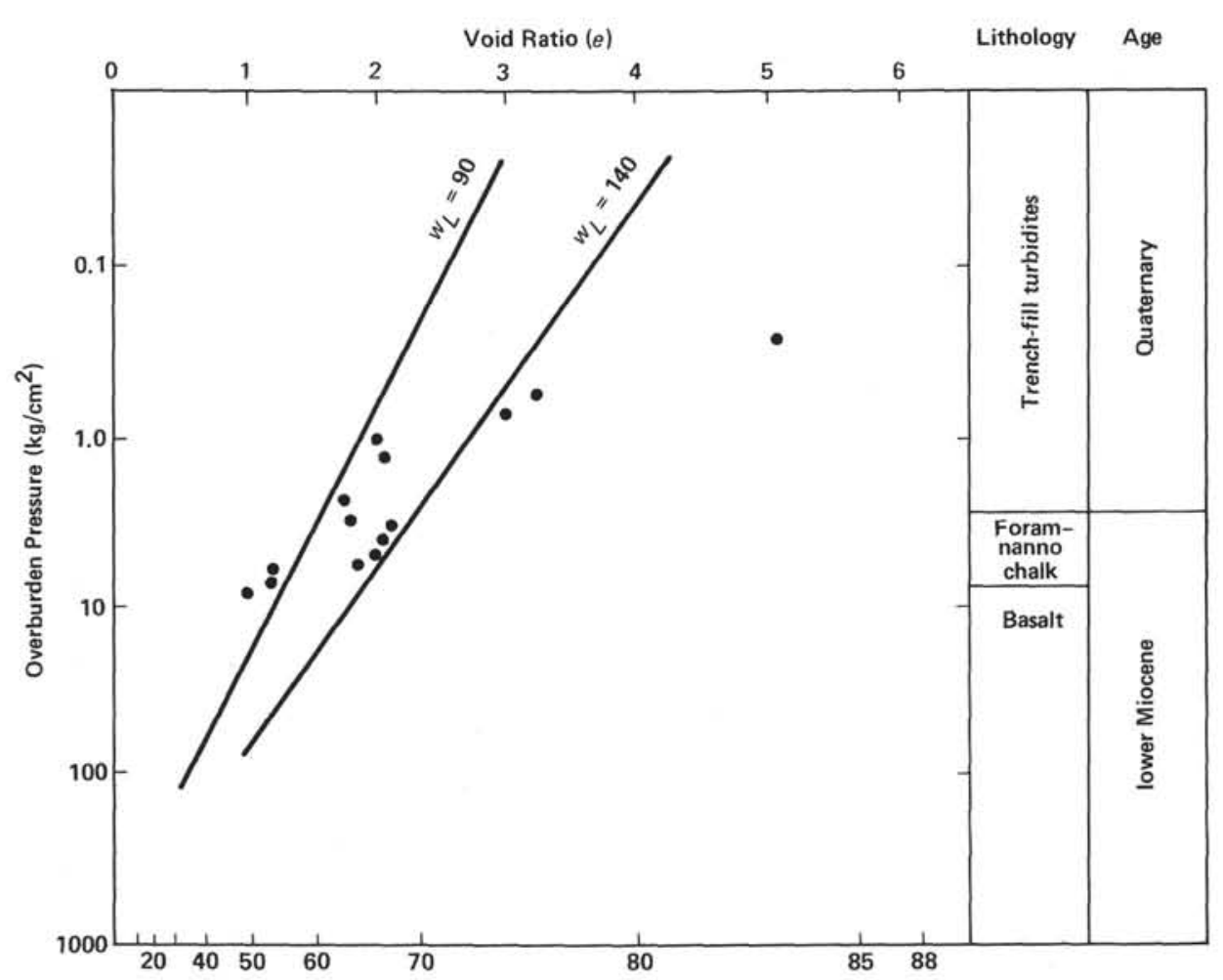

Figure 17. Sedimentation-compression diagram, Site 500.

of sediment accumulation may allow dewatering to occur to such an extent that the resulting deposit develops a rigid framework, resulting in an overcompacted sediment. Conversely, greater depositional rates may trap interstitial water in impermeable sediments, causing a buildup of pore pressure in excess of that which would occur under slower rates of deposition, thus retarding framework development. Pelagic oozes are composed of biogenic remains having large volumes of water-filled voids, which may drain slower under increased overburden pressures than terrigenous sediments and lead to undercompaction. If sedimentation occurs within a basin that is being reduced in volume through lateral pressures associated with subduction, the "squeezing" resulting from such forces would accelerate the dewatering process, resulting in overcompaction at shallow depths (Carson, 1977). A significant feature in all Leg 67 continental slope sites was the presence of a layer of gas hydrates at about $\mathbf{3 0 0}$ meters sub-bottom depth. Decomposition of the upper portion of the gas hydrate horizon may add methane and ethane to the overlying sediments, lowering their unit weight and resulting in an undercompacted sediment (Hedberg, 1980).

\section{General Compaction Patterns}

At Site 494, located on the landward margin of the lower Trench slope, the greatest compaction of all the holes drilled on Leg 67 is in evidence. The Site 494 compaction curve is nearly identical with the theoretical normal compaction curve for terrigenous sediments. However, the lithologically diverse sediment with a large biogenic component that was recovered at this site should be expected to compact more like a pelagic or diatomaceous sediment. Something occurred to cause the sediment at this site to dewater more rapidly than expected. Physical properties (i.e., GRAPE density and water content) change rapidly in the upper 50 meters.

The unexpected occurrence of overcompacted sediments at shallow depths $(50 \mathrm{~m})$ requires some discussion. Overcompaction may result from several processes:

1) Removal of sedimentary overburden, either through erosion or faulting.

2) Dessication, with the development of negative pore pressures.

3) Cementation and recrystallization within the sediment mass.

These processes are the obvious ones responsible for overcompaction. However, any condition that would allow a rigid sedimentary framework to develop simultaneously with rapid dewatering, resulting in a deposit that would have less-than-hydrostatic pore pressures, will give rise to a condition of overcompaction.

Such conditions might be created in oceanic trench environments through sudden downslope mass movements and/or lateral compressive forces that would "squeeze" the sediments. In the former, a disrupted sedimentary fabric would allow rapid egress of interstitial waters immediately after downslope movement had terminated. The resulting deposit would likely compact rapidly due to high permeability. In the latter, tectonically induced forces associated with lateral compression may be responsible for rapid dewatering and overcompaction. These conditions have been suggested by Arthur, Carson, and von Huene (1980) to explain the anom- 


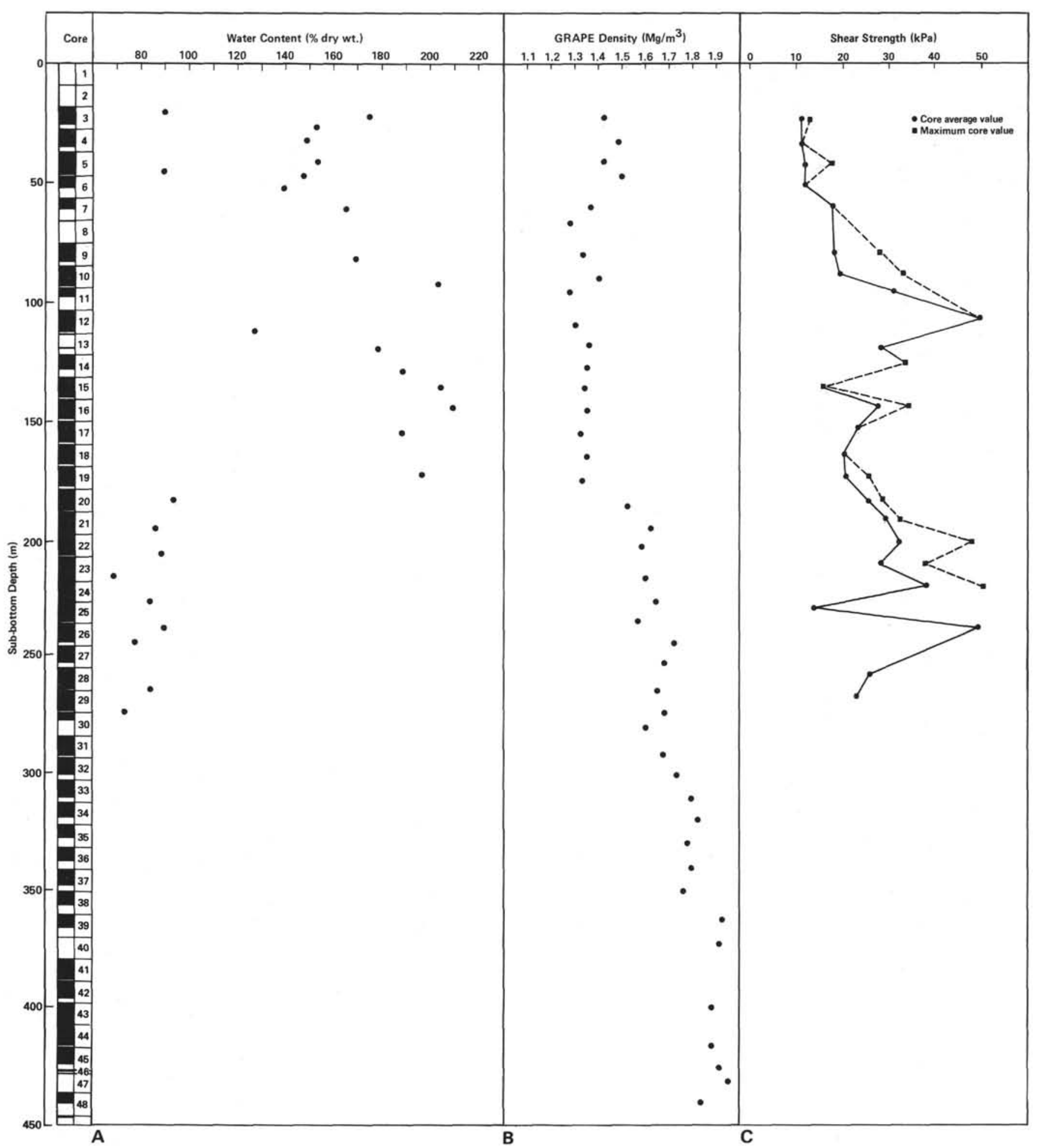

Figure 18. A. Water content, Site 495. B. GRAPE density, Site 495. C. Shear strength, Site 495.

alous occurrence of compacted sediments at shallow depths on the trench lower slope of the Japan Trench (Site 434, DSDP Leg 56).

It is not possible to determine the nature of the events that caused the change in compaction characteristics of the sediments from physical property data alone. It is possible, however, to determine the timing of the event that initiated the change. Sedimentation-compression diagrams (Fig. 12) indicates that an event occurred in the middle Quaternary involving Hole 494, Core 4 and Hole 494A, Core 1. A second event may have occurred in the lower middle Pleistocene involving Hole 494A, Cores 4 to 6 . The presence of "drilling breccia,"' including micritic limestone cobbles, fragments of pelecypod 


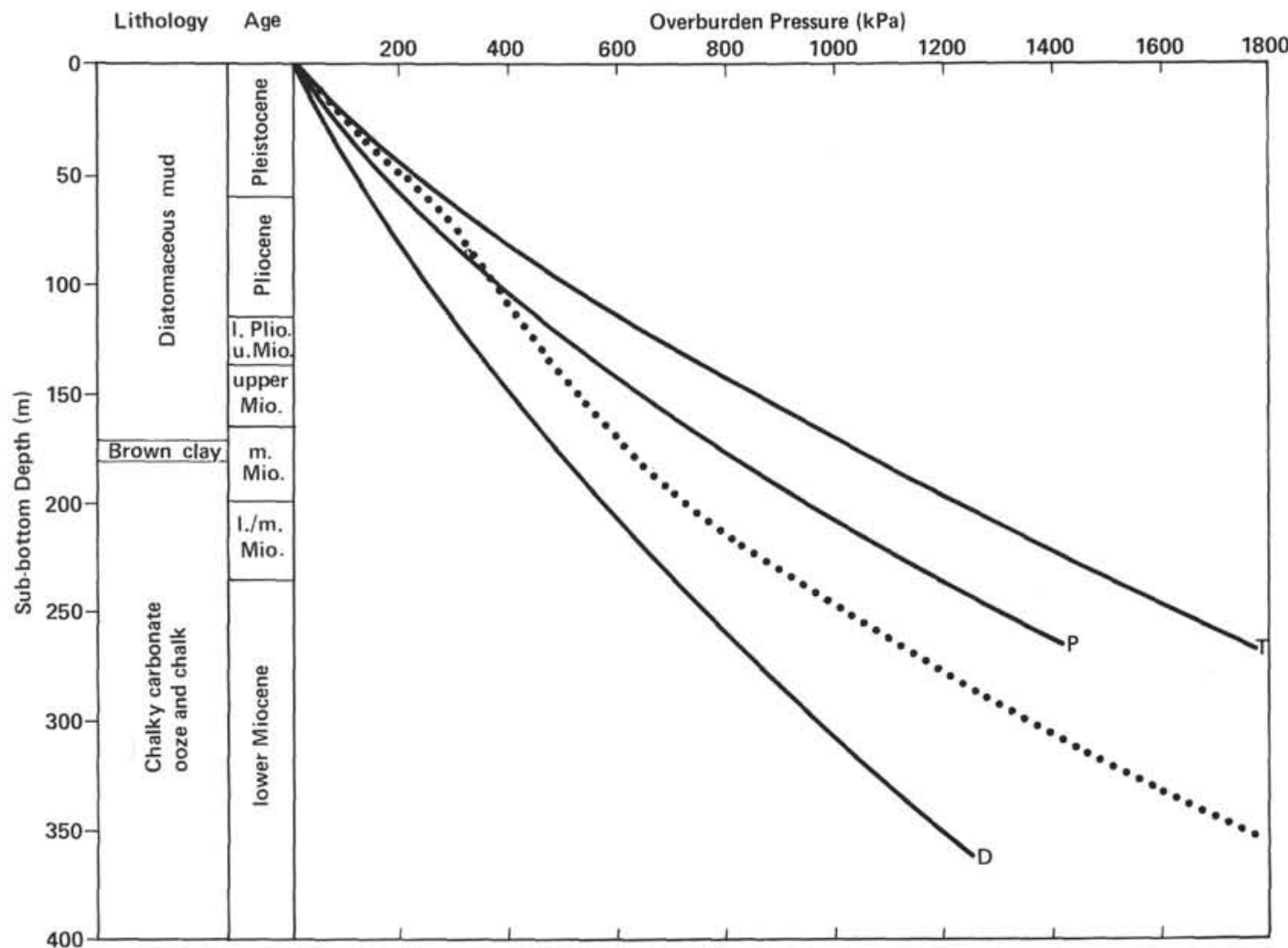

Figure 19. Compaction curve, Site 495.

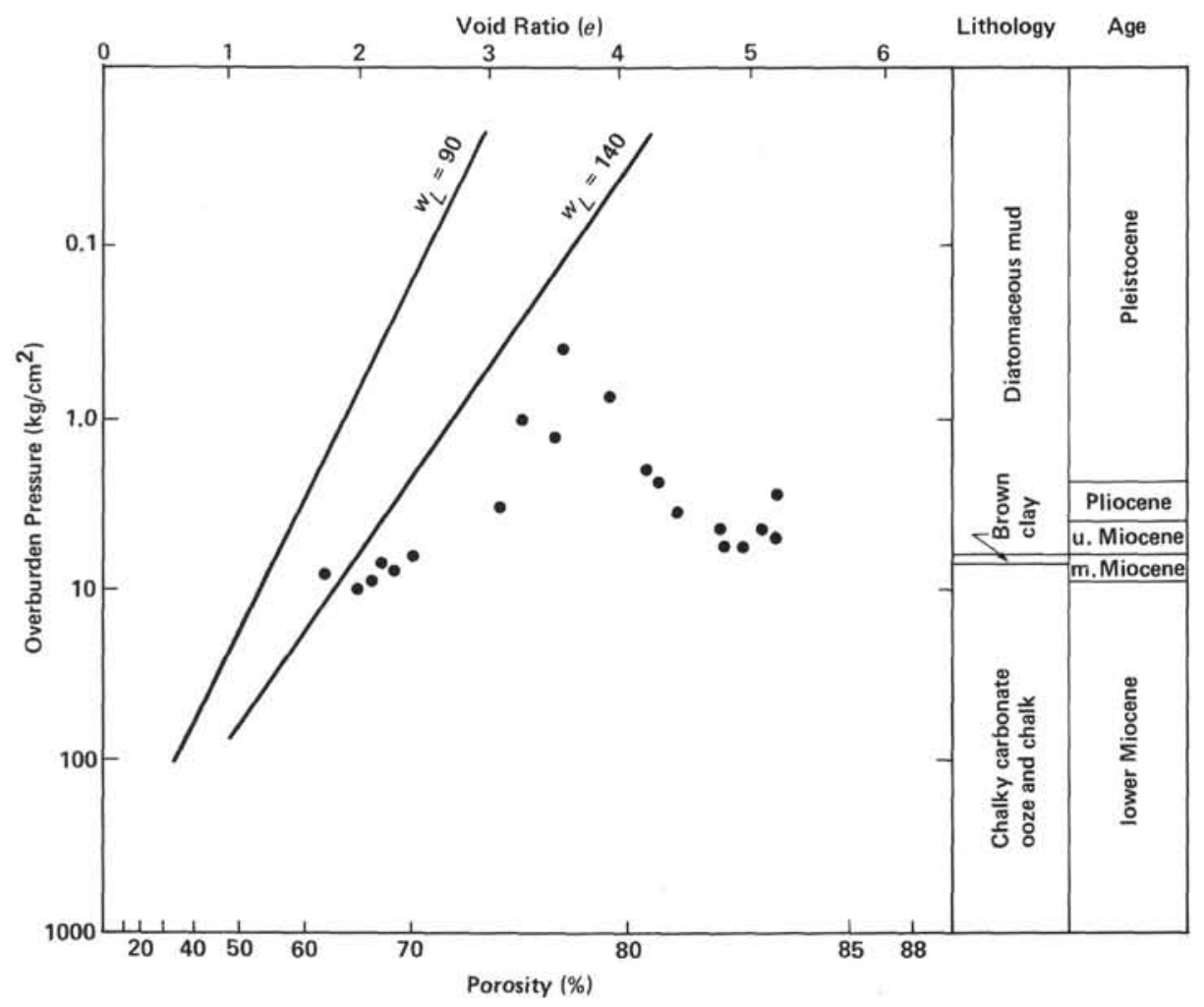

Figure 20. Sedimentation-compression diagram, Site 495. 
valves, and a rounded cobble of coarse-grained quartz diorite, is noted in the lithologic description of Hole 494A, Cores 4 through 6 . Several pebbles were also observed at Hole 494, Core 4 and Hole 494A, Core 1, otherwise described as dark gray, diatomaceous mud. This indicates displacement of material from shallow water according to some mass transfer mechanism, as suggested by Field (1981).

Sites 499 and 500 appear to be overcompacted, although to a much lesser degree than Site 494. Both are located on the floor of the Middle America Trench. At both sites, the compaction curve falls below that for normally compacting pelagic sediments within the upper 50 meters. This indicates a degree of undercompaction within the upper trench-filling sediments.

Methane gas is being generated in the turbidites that have accumulated in the anoxic environment of the Trench. Low unit weight and low shear strength is characteristic of these sediments because of the disturbing effects of the gas (Hedberg, 1974; Faas and Wartel, 1977; Tompkins and Shephard, 1979). High compressibility is seen in the pattern of void ratio reduction that follows the trend for sediments of medium to high plasticity. The turbidites accumulated rapidly $(300 \mathrm{~m} / \mathrm{m} . \mathrm{y}$, Site $499 ; 70 \mathrm{~m} / \mathrm{m} . \mathrm{y}$. , Site 500 ), probably in periodic pulses, leaving little opportunity for dewatering to occur from the underlying sediment. Rapid accumulation of the sediments, coupled with methanogenesis in an anoxic environment, is responsible for the undercompaction of these sediments. Below 50 meters sub-bottom depth, compaction curves swerve sharply upward (especially at Site 499) and reflect increasing lithification. At Site 499, this change occurs within the upper Quaternary trenchfilling sediments; at Site 500 it becomes most noticeable in the lower Miocene chalks.

Sites 496 and 497 on the Guatemalan continental slope reveal undercompaction, most significantly at Site 496 . Total organic carbon is quite high in these sediments, averaging $2.77 \%$ (range: $1.99-4.26 \%$ ) (Faas, this volume). During processing of the sediments, the odor of $\mathrm{H}_{2} \mathrm{~S}$ was detected. Undercompaction throughout this section at both sites is believed to be caused by increased pore pressures associated with in situ gas generation. At Site 497 , the void ratio data are especially revealing. Figure 9 shows that the void ratio decreased from 3.62 to 2.50 from the mudline down to 40 meters, followed by a minor change (2.50-2.10) between 70 and 280 meters. Compressibility (reduction in void ratio with increment of overburden pressure) in high void ratio sediments is usually very high, decreasing rapidly between $1.0 \mathrm{~kg} / \mathrm{cm}^{2}$ $(98.0 \mathrm{kPa})$ and $10.0 \mathrm{~kg} / \mathrm{cm}^{2}(980.6 \mathrm{kPa})$ of overburden pressure. Bryant, DeFlache, and Trabant (1974) show an average void ratio reduction of 0.94 from laboratory consolidation tests on four sediment samples from the Gulf of Mexico, consolidated through an overburden pressure interval from 1 to $10 \mathrm{~kg} / \mathrm{cm}^{2}(980 \mathrm{kPa}-980.6$ $\mathrm{kPa}$ ). The sediment at Site 497 was reduced 0.85 void ratio units through the same range of overburden pressures $\left(1 \mathrm{~kg} / \mathrm{cm}^{2}[98.0 \mathrm{kPa}]\right.$ at $20 \mathrm{~m}$ to $10 \mathrm{~kg} / \mathrm{cm}^{2}[980.6$ $\mathrm{kPa}]$ at $215 \mathrm{~m}$ ). The void ratio of sediments at Site 496 was also reduced from 2.72 to 2.00 under the same range of overburden pressures, but $10 \mathrm{~kg} / \mathrm{cm}^{2}(980.6$ $\mathrm{kPa}$ ) overburden pressure was not reached until 265 meters sub-bottom depth. Consequently, Site 496 is undercompacted relative to Site 497 , which reached an overburden pressure of $10 \mathrm{~kg} / \mathrm{cm}^{2}(980.6 \mathrm{kPa})$ at 215 meters (Fig. 21). This is also shown by the sedimentation-compression diagrams (Figs. 6 and 9). The lack of significant void ratio change can be attributed to excess pore pressure generated by gas expansion in the interstitial waters of the sediment. These pressures were not allowed to dissipate due to expected low permeability of the hemipelagic and diatomaceous muds within the upper 50 meters. (Bryant, Hottman, and Trabant [1975] found permeabilities between $10^{-5}$ to $10^{-6}$ darcies in high-porosity muds from the Gulf of Mexico.)

The change toward normal compaction (upward change in slope) that occurs at both sites between 200 and 250 meters coincides with the occurrence of lithified upper Pliocene limestones and mudstones (Fig. 2). Sedimentation rates also change significantly between these trends; within the Quaternary, rates changed from 205 $\mathrm{m} / \mathrm{m} . \mathrm{y}$. at Site 496 to $150 \mathrm{~m} / \mathrm{m}$.y. at Site 497 (von Huene and Aubouin, et al., 1980). In the Pliocene section, rates of $7 \mathrm{~m} / \mathrm{m}$.y. to $40 \mathrm{~m} / \mathrm{m}$.y. were determined. Normal compaction of the Pliocene sediments may be attributed to the slow rate of deposition that allowed sediment to dewater efficiently. Compressibility at both sites is nearly identical, attesting to the uniform composition of the sediments.

Figure 19 shows a complex compaction curve for Site 495. From the mudline down to the base of the Pleistocene $(57 \mathrm{~m})$, the diatomaceous mud follows the trend of normally compacting terrigenous sediments. They are considered to be overcompacted hemipelagic sediments. Between 60 and 180 meters the compaction curve of the Pliocene and upper Miocene diatomaceous muds deviates toward the diatom ooze compaction curve and exhibits undercompaction. Through the middle Miocene to about middle lower Miocene $(200 \mathrm{~m})$, the compaction curve follows a normally compacting trend, changing within lower Miocene chalks to follow an overcompacted curve to the base of the hole.

Two explanations are suggested for this complex behavior. The first deals with the fact that the sediment accumulated on a moving plate. The older, early Miocene section is more compacted, perhaps due to time, lithification, and distance from a terrestrial sedimentary source. Normal compaction proceeded through late middle Miocene to early Pliocene as the plate approached the continent and received greater hemipelagic sedimentation. From early Pliocene to the present, increased loading by increased terrigenous material may have created apparent overcompaction in the upper 57 meters of Pleistocene sediment. Sediment accumulation rates show an increase from $11 \mathrm{~m} / \mathrm{m} . \mathrm{y}$. in middle Miocene to $37 \mathrm{~m} /$ m.y. in Pleistocene. However, it seems unlikely that 37 $\mathrm{m} / \mathrm{m}$.y. is a sediment load significant enough to cause the observed overcompaction. It may be more useful to consider overcompaction developing as the result of slow sediment accumulation and consequent dewatering. In that case, the Pliocene and upper Miocene diatoma- 


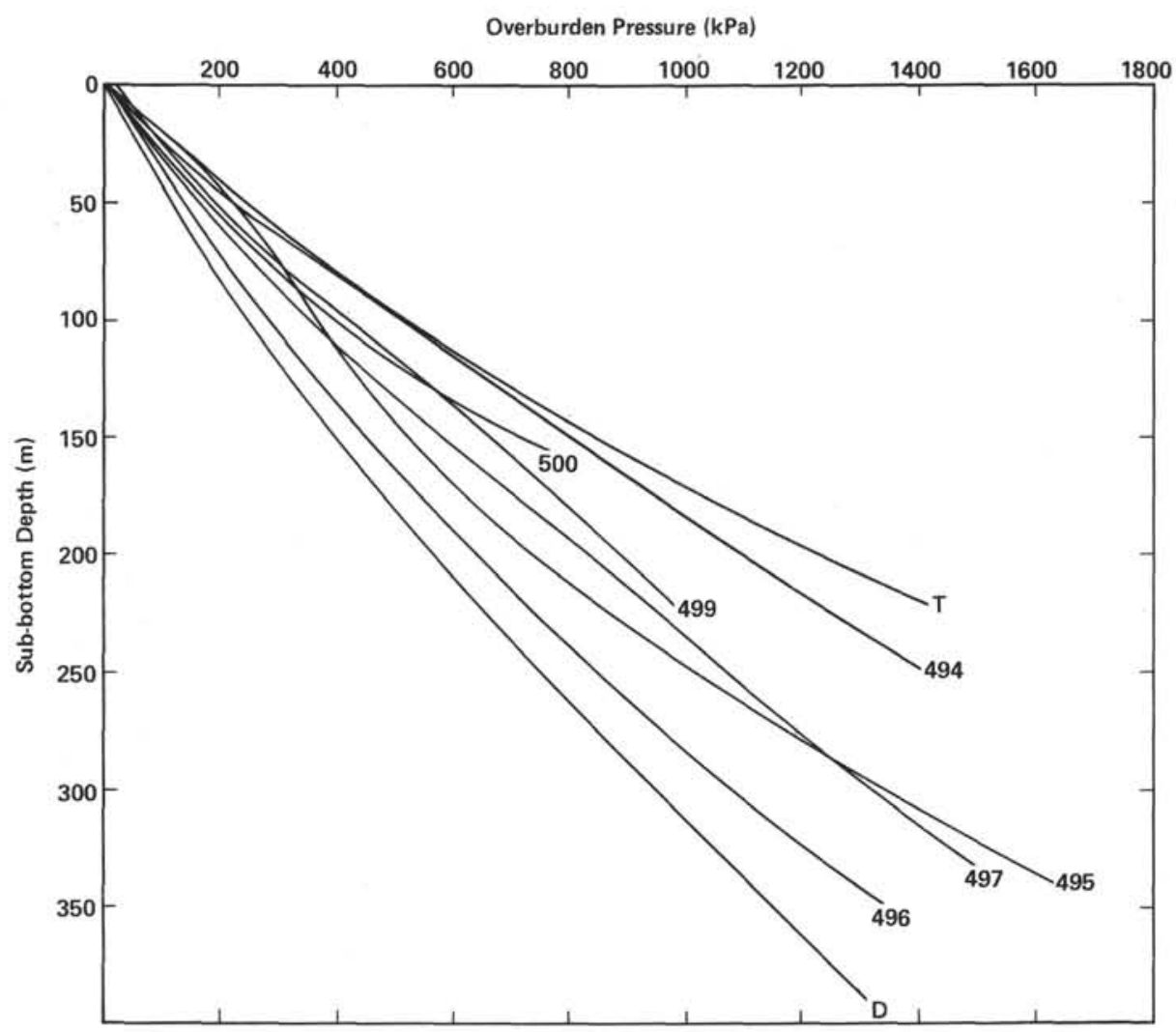

Figure 21. General compaction patterns, Leg $67(\mathrm{~T}=$ terrigenous; $\mathrm{D}=$ diatomaceous $)$.

ceous muds should show even greater overcompactionbut they appear to be undercompacted.

The second explanation for the apparent overcompaction of the Pleistocene sediments has to do with the tectonic setting of the oceanic Plate. While entering the subduction zone at the outer Trench, normal faulting created a horst and graben topography. Site 495 lies approximately 2000 meters above the Trench floor. Upward vertical movement of the Site 495 horst block, occurring during the Pleistocene as that portion of the Plate entered the subduction zone, may have been accompanied by subaqueous ground shaking that served to dewater the Pleistocene sedimentary cover. Several intervals of unusually low water contents are shown in Figure 18A, and the sediments are unusually dense (Fig. $18 \mathrm{~B})$. The low shear strength $(10-12 \mathrm{kPa})$ in the upper 50 meters would reflect an apparent in situ "remolding" of the Pleistocene sediments. The Pliocene and upper Miocene sediments become confined between the overcompacted Pleistocene sediment and the older lithified chalks, thus becoming undercompacted with excess pore water pressure ( $1.1 \%$ compaction). The previously deposited middle and lower Miocene chalks were unaffected by this vertical movement, as they were already lithified when movement began.

Figure 21 shows composite compaction patterns for the Leg 67 sites. The theoretical compaction curves for terrigenous sediment and diatomaceous ooze are plotted and form a limiting envelope, within which all the individual compaction curves are located. Sites 494, 500, and 499 lie toward the terrigenous curve and indicate overcompaction, with Site 494 showing the greatest compaction.

Site 497 shows a generally normally compacted curve, lying between the terrigenous sediment and diatomaceous ooze curves. Site 496 lies toward the diatomaceous ooze curve and appears generally undercompacted. Both of these sites are located on the Guatemalan continental slope.

Site 495, on the Cocos Plate, shows various forms of compaction behavior.

\section{Decompaction Analysis}

If the conclusions drawn from the preceding analysis of compaction behavior are correct, they should be substantiated by a "decompaction" analysis. Such an analysis is performed by expanding the sedimentary section back to its original depositional void ratio. Hamilton (1976) presents the analysis in detail and suggests the proper initial void ratio to use for the commonly occurring marine sediments. When it became clear that the sediment was a mixture of two pure sediment types (e.g., hemipelagic diatomaceous mud), the initial void ratio selected was taken as the average of the two void ratios for each type. Sandy turbidites were considered to be terrigenous sediments with an initial void ratio of 2.57 (Table 1).

Decompaction was done two ways. In the first, variable intervals were decompacted following lithologic changes as indicated by the Initial Core Descriptions for Leg 67. For example, in Site 496, the first 17 meters of diatomaceous mud was decompacted, followed by 47 
Table 1. Decompaction values for normally compacting, commonly occurring marine sediments (Hamilton, 1976). ${ }^{\text {a }}$

\begin{tabular}{|c|c|c|c|c|c|}
\hline$H_{p}$ & $e_{o}$ & $e_{p}$ & $H_{O}$ & $\begin{array}{l}\text { Compaction } \\
\text { per Increment } \\
(\%)\end{array}$ & $\begin{array}{c}\text { Total } \\
\text { Compaction } \\
(\%)\end{array}$ \\
\hline
\end{tabular}

Deep Sea Terrigenous Sediment

$\begin{array}{rrrrr}0 & 2.57 & - & - & - \\ 50 & & 2.14 & 56.85 & 12.0 \\ 100 & & 1.81 & 63.52 & 21.3 \\ 150 & & 1.56 & 69.72 & 28.3 \\ 200 & & 1.35 & 75.96 & 34.1 \\ 300 & & 1.02 & 176.79 & 43.4 \\ 400 & & 0.80 & 198.33 & 49.6 \\ 500 & & 0.64 & 217.69 & 54.0 \\ & & & 858.86 & \end{array}$

Deep Sea Diatomaceous Ooze

$\begin{array}{rrrrr}0 & 6.19 & - & - & - \\ 50 & & 5.06 & 51.07 & 2.1 \\ 100 & & 4.32 & 58.18 & 14.0 \\ 150 & & 3.76 & 65.02 & 23.1 \\ 200 & & 3.37 & 70.82 & 29.4 \\ 300 & & 2.85 & 160.78 & 37.8 \\ 400 & & 2.57 & 173.39 & 42.3 \\ 500 & & 2.45 & 179.42 & 44.3 \\ & & & 958.68 & \end{array}$

Deep Sea Pelagic Clay

\begin{tabular}{|c|c|c|c|}
\hline $\begin{array}{ll}0 & 4.32\end{array}$ & - & - & - \\
\hline 50 & 3.42 & 60.18 & 16.9 \\
\hline 100 & 2.72 & 71.50 & 30.0 \\
\hline 150 & 2.22 & 82.61 & 39.5 \\
\hline 200 & 1.81 & 94.66 & 47.2 \\
\hline 250 & 1.50 & 106.40 & 53.0 \\
\hline 300 & 1.25 & 118.22 & 57.7 \\
\hline & & 533.57 & \\
\hline
\end{tabular}

a Decompaction formula: $H_{O}=H_{p}\left(I+e_{o}\right) /\left(1+e_{p}\right.$ ) (Hamilton, 1976)

where

$$
\begin{aligned}
H_{O} & =\text { original thickness } \\
H_{p} & =\text { present thickness, } \\
e_{O} & =\text { original void ratio, and } \\
e_{p} & =\text { present void ratio. }
\end{aligned}
$$

meters of hemipelagic mud. In this way, total compaction and compaction per lithologic unit for each site could be observed. Table 2 shows the effect of lithology on compaction. Both "terrigenous sandy mud" and "diatom ooze" show maximum compaction, whereas "turbidites," “"pelagic clay," and "calcareous sediment" compact to lesser degrees.

In the second approach, each 9.5-meter core was decompacted using the average measured void ratio $\left(e_{p}\right)$ for the core (in some cases, as many as six measurements formed the average; in some cores, only one measurement was made). Where gaps due to poor recovery occurred, the average measured void ratio for the previous core was extrapolated through the missing interval. Initial void ratios were chosen that seemed to correspond best to the generalized unit stratigraphy and were maintained throughout the unit. This approach deemphasized

\begin{tabular}{|c|c|c|c|c|c|c|c|}
\hline Sediment Type & 494 & 495 & 496 & 497 & 499 & 500 & $\begin{array}{c}\text { Average } \\
\text { Compaction } \\
(\% 0)\end{array}$ \\
\hline $\begin{array}{l}\text { Terrigenous sandy } \\
\text { mud }\end{array}$ & 66 & & 53.2 & 30.5 & & & 49.9 \\
\hline \multirow{2}{*}{$\begin{array}{l}\text { Calcareous sediment } \\
\text { (nannofossil) }\end{array}$} & & & & 11.3 & 18.9 & & \\
\hline & & 20.8 & 17.3 & $\begin{array}{l}12.8 \\
19.8\end{array}$ & 20.2 & 47.6 & 21.2 \\
\hline \multirow[t]{2}{*}{ Pelagic clay } & 41.1 & 13.5 & 15.7 & 30.2 & & & 27.6 \\
\hline & & & 45.5 & 19.7 & & & \\
\hline \multirow[t]{2}{*}{ Diatom mud } & & & & & 35.9 & & \\
\hline & 57 & 18.8 & 54.0 & 57.0 & $\begin{array}{l}49.1 \\
36.8\end{array}$ & 32.7 & 43.4 \\
\hline Turbidites & & & & & 31.1 & 21.5 & 26.3 \\
\hline
\end{tabular}
specific lithologic control of compaction but provided an overall view of total compaction at each site. Table 3
Table 2. Decompaction values for lithologies at each site, Leg 67.

Table 3. Percent compaction-Leg 67 sites.

\begin{tabular}{lccl}
\hline & \multicolumn{2}{c}{ Technique } & \\
\cline { 2 - 3 } Hole & Specific & General & \multicolumn{1}{c}{ Location } \\
\hline 496 & 38.5 & 37.8 & Continental slope \\
497 & 31.0 & 31.0 & Continental slope \\
$499 \mathrm{~A}$ & 35.5 & 43.0 & Middle America Trench \\
500 & 37.7 & 34.0 & Middle America Trench \\
495 & 18.6 & 11.0 & Cocos Plate \\
494 & 44.5 & 44.0 & Inner Trench wall \\
\hline
\end{tabular}

presents the compaction values determined for each site by both techniques.

The analysis revealed three general compaction patterns among all the sites (Fig. 22). Sites 496 and 497 on the continental slope compacted between 31 and $38 \%$, with greater compaction occurring at Site 496, located closer to the mouth of the San José sea valley. Site 495, on the oceanic Plate showed least compaction (11.0$18.6 \%$, depending on technique), attributable to low sediment loading rates. The upper diatomaceous unit shows overcompaction from the mudline down to 57 meters, corresponding with low sedimentation rates (37 $\mathrm{m} / \mathrm{m}$.y.) through the Quaternary (von Huene, Aubouin, et al., 1980). Undercompaction increases in the siliceous muds toward the base of the upper middle Miocene, becoming maximum at 180 meters. Normal compaction occurs in the lower Miocene calcareous oozes and chalks to the basalt. These changes can be clearly seen in Figure 19.

Greatest compaction was observed at Site 494, located at the base of the Trench slope. The column was composed of diatomaceous muds, terrigenous sandy mud and mudstones, and a basal pelagic clay. Computed compaction was $44.5 \%$, with $57 \%$ compaction in the diatomaceous muds, $66 \%$ in the terrigenous sandy mud and mudstones, and $41 \%$ in the pelagic clay.

Both Trench sites (499 and 500) showed significant but not unusual compaction. Both are characterized by a thick turbidite sequence interbedded with hemipelagic sediments. Decompaction according to specific lithologies is difficult, but it indicated similar behavior at the two sites. The general compaction analysis showed differences between the two sites, with Site $499(43.0 \%$ compaction) comparing closely to Site 494 on the inner Trench slope. 


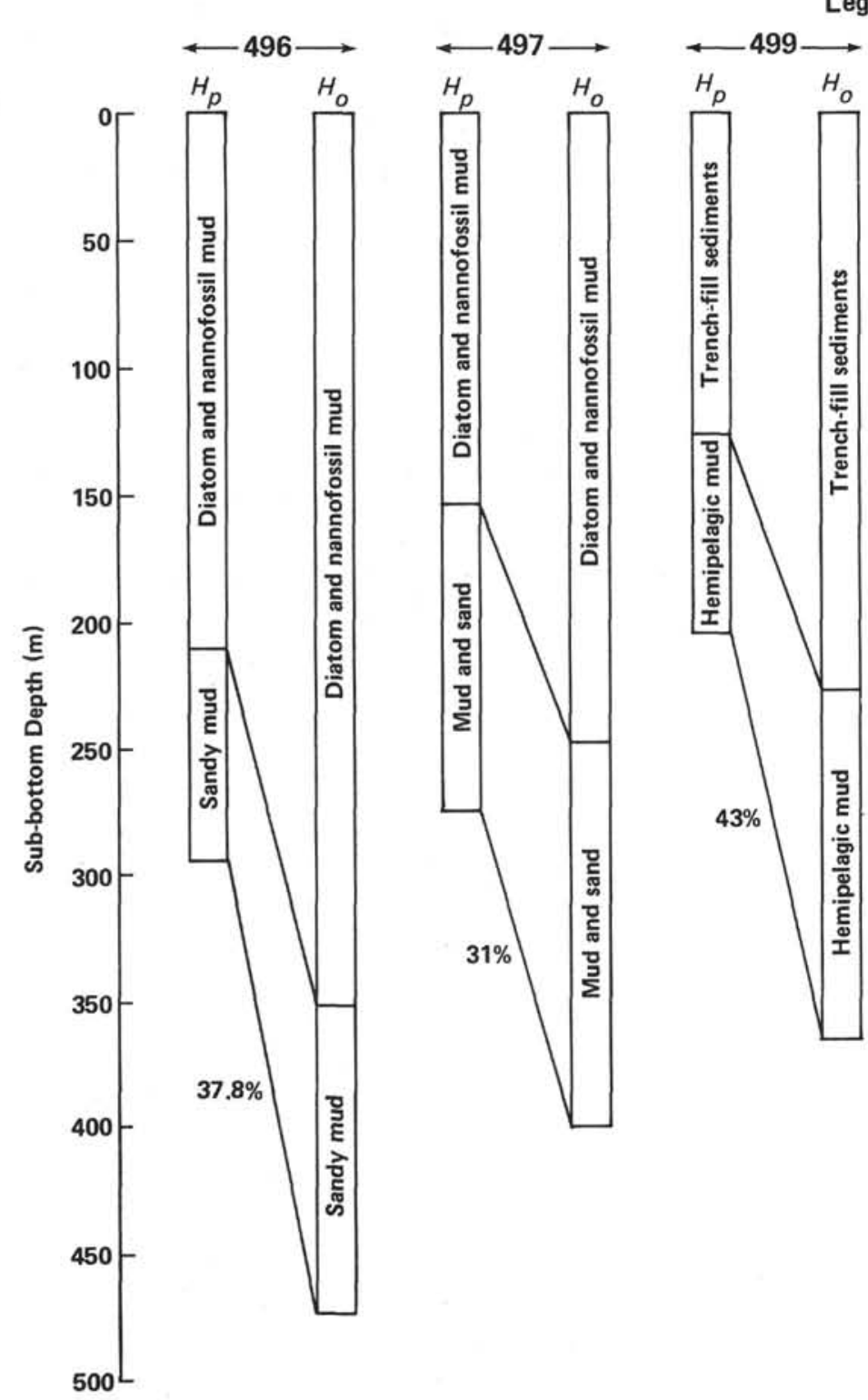

Leg 67 Sites
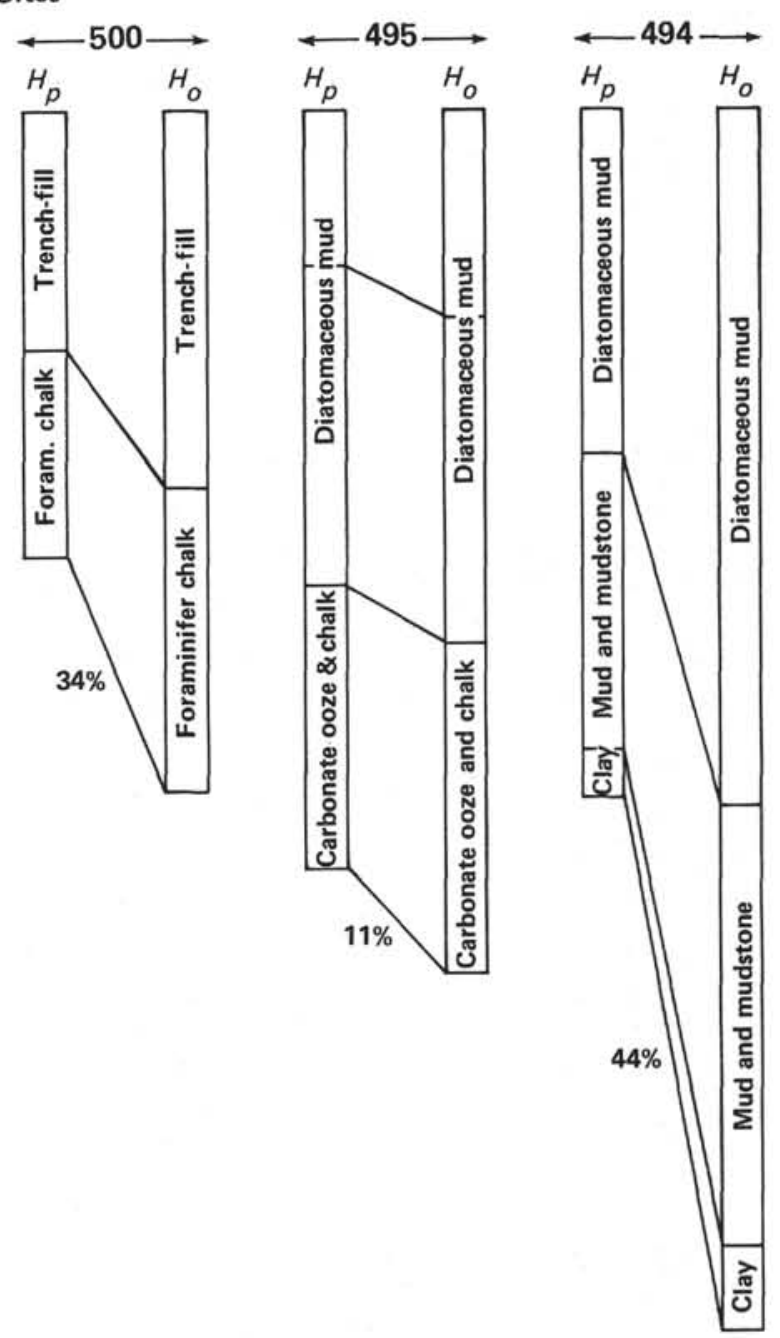

Figure 22. Decompaction diagram of Leg 67 holes. ( $H_{p}=$ present thickness, $H_{o}=$ original thickness.)

Decompaction analysis generally follows the compaction trends revealed in Figure 21, with a few exceptions. In Figure 21, Site 496 appears least compacted. Decompaction shows it to be $38.0 \%$ compacted and Site 495 the least compacted $(11.0-18.6 \%)$. Site 494 still indicates overcompaction $(44.5 \%)$.

\section{SUMMARY}

Regular patterns of gravitational compaction behavior occur in sediment cores taken from a transect down the Guatemalan continental slope, across the Middle America Trench, and onto the Cocos Plate, and are related to rates of lithostatic loading, sediment type, and geochemical environment of the depositional site. Lateral compressive forces associated with a convergent margin do not seem important except possibly in the case of Site 494, located on the Trench lower slope.
Sediments on the continental slope show the same degree of compaction as sediments in the Middle America Trench. However, they tend to follow a compaction curve intermediate between pelagic clays and diatom ooze. It is likely that this compaction pattern may arise from the ubiquitous presence of methane gas, derived either from bacterial decomposition of organic matter or from decomposition of a gas hydrate zone of unknown thickness that occurs at about 300 meters subbottom depth (von Huene, Aubouin, et al., 1980). The overall effect is to reduce the lithostatic load in the upper 300 meters and create zones of undercompaction in the relatively impermeable fine-grained sediments. The Trench sediments, on the other hand, follow a compaction curve intermediate between pelagic clays and terrigenous sediments. This results from the mixing of pelagic sediments with the terrestrially derived turbidites. 
At Site 494 on the Trench inner slope, several events have occurred that caused overcompaction at shallow depths. They are likely associated with the sudden imposition of a vertical lithostatic load, perhaps caused by massive subaqueous slumps, possibly reflecting periodic lateral compressive stresses associated with active subduction or the process of subduction erosion (von Huene and Aubouin, et al., 1980). Data are both incomplete and insufficient to provide an answer to this problem.

The compaction behavior of the sediments on the Cocos Plate is controlled by sedimentation rate, sediment type, and tectonic events. Slowly accumulating hemipelagic sediments appear overcompacted. The water-rich siliceous oozes below the impermeable hemipelagic clays show relative undercompaction due to impeded drainage. Lithified chalks appear normal to overcompacted as void spaces are filled with recrystallized calcite.

\section{REFERENCES}

Arthur, M. A., Carson, B., and von Huene, R., 1980. Initial tectonic deformation of hemipelagic sediment at the leading edge of the Japan convergent margin. In Scientific Party, Init. Repts. DSDP, 56, 57, Pt 1: Washington (U.S. Govt. Printing Office), 569-613.

Athy, L. F., 1930. Density, porosity, and compaction of sedimentary rocks. Am. Assoc. Pet. Geol. Bull., 14(1):1-24.

Bishop, R. S., 1979. Calculated compaction states of thick abnormally pressured shales. Am. Assoc. Pet. Geol. Bull., 63(6):918-933.

Bryant, W. R., DeFlache, A. P., and Trabant, P. K., 1974. Consolidation of marine clays and carbonates. In Inderbitzen, A. L. (Ed.), Deep-Sea Sediments: Physical and Mechanical Properties: New York (Plenum Press), pp. 209-244.

Bryant, W. R., Hottman, W., and Trabant, P. K., 1975. Permeability of unconsolidated and consolidated marine sediments, Gulf of Mexico. Mar. Geotechnol., 1(1):1-14.

Burst, J. F., 1969. Diagrams of Gulf Coast clayey sediment and its possible relation to petroleum migration. Am. Assoc. Pet. Geol. Bull., 53(1):73-93.

Carson, B., 1977. Tectonically induced deformation of deep sea sediments of Washington and Northern Oregon: mechanical consolidation. Mar. Geol., 24:289-307.

Evans, H. B., and Cotterell, C. H., 1970. Gamma ray attenuation density scanner. In Peterson, M. N. A., Edgar, N. T., et al., Init.
Repts. DSDP, 2: Washington (U.S. Govt. Printing Office), 460-462.

Faas, R. W., and S. Wartel, 1977. The effect of gas bubble formation on the physical and engineering properties of recently deposited fine-grained sediments. Geol. Mijnbouw, 56(3):211-218.

Field, M. E., 1981. Sediment mass-transport in basins: controls and patterns. In Douglas, R. G., Colburn, I. P., Gorsline, D. S. (Eds.), Depositional System of Active Continental Margin Basins: SEPM Short Course, Pacific Section, San Francisco, pp. 61-83.

Hamilton, E. L., 1959. Thickness and consolidation of deep sea sediments. Bull. Geol. Soc. Am., 70:1399-1424. 1960. Ocean basin ages and amounts of original sediments. J. Sediment. Petrol, 30(3):370-379.

1976. Variations of density and porosity with depth in deepsea sediments. J. Sediment. Petrol. 46(2):280-300.

Hedberg, H. D., 1936. Gravitational compaction of clays and shales. Am. J. Sci., 31:241-287.

1974. Relation of methane generation to undercompacted shales, shale diapirs, and mud volcanos. Am. Assoc. Pet. Geol. Bull., 58(4):661-673.

1980. Methane generation and petroleum migration. Am. Assoc Pet. Geol. Stud. Geol., 10:179-206.

Lambe, T. W., 1951. Soil Testing for Engineers: New York (John Wiley \& Sons).

Meade, R. H., 1966. Factors influencing the early stages of compaction of clays and sands: review. J. Sediment. Petrol., 36(4): $1085-1101$.

Powers, M. C., 1976. Fluid-release mechanism in compacting marine mudrocks and their importance in oil exploration. Am. Assoc. Pet. Geol. Bull., 51(7):1240-1254.

Riecke, H. H., III, and Chilingarian, G. V., 1974. Compaction of Argillaceous Sediments: Amsterdam (Elsevier).

Skempton, A. W., 1970. The consolidation of clays by gravitational compaction. Q. J. Geol. Soc. London, 125(3):373-412.

Tompkins, R. E., and Shephard, L. E., 1979. Orca Basin: depositional processes, geotechnical properties and clay mineralogy of Holocene sediments within an anoxic hypersaline basin, northwest Gulf of Mexico. Mar. Geol., 33:221-238.

von Huene, R., Aubouin, J., Azéma, J., Blackinton, G., Carter, J. A., Coulbourn, W. T., Cowan, D. S., Curiale, J. A., Dengo, C. A., Faas, R. W., Harrison, W., Hesse, R., Hussong, D. M., Ladd, J. W., Muzylöv, N. Shiki, T., Thompson, P. R., and Westberg, J., 1980. Leg 67: The Deep Sea Drilling Project Mid-America Trench transect off Guatemala. Bull. Geol. Soc. Am., 91(1):421-432.

Weller, J. M., 1959. Compaction of sediments. Am. Assoc. Pet. Geol. Bull., 43:273-310. 